\title{
Predicting Rank Attainment in Political Science: What Else Besides Publications Affects Promotion?
}

Vicki L. Hesli, University of Iowa

Jae Mook Lee, University of Iowa

Sara McLaughlin Mitchell, University of Iowa

ABSTRACT We report the results of hypotheses tests about the effects of several measures of research, teaching, and service on the likelihood of achieving the ranks of associate and full professor. In conducting these tests, we control for institutional and individual background characteristics. We focus our tests on the link between productivity and academic rank and explore whether this relationship reveals a gender dimension. The analyses are based on an APSA-sponsored survey of all faculty members in departments of political science (government, public affairs, and international relations) in the United States.

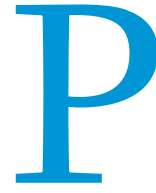

romotion decisions are among the most important choices that academic departments make. Generally, promotion from assistant to associate professor brings the decisive reward of tenure-an almost certain guarantee of continuing employment. Wise promotion decisions enhance a department's prestige, while failure to promote a capable scholar means losing talent to another university or possibly an end to a promising academic career (Long, Allison, and McGinnis 1993, 703). Higher rank yields better salaries and more influence within the department.

An extensive literature exists on the subject of academic promotion. This literature is based on studies of several different disciplines, from medicine and economics to the social sciences and humanities. Our own analyses of the factors affecting promotion, presented in the second part of this article, are based solely on the discipline of political science. For these analyses, we rely on a 2009 APSA-sponsored survey of all faculty employed in political science departments (including departments of government and public affairs) throughout the United States. (Appendix A provides a description of the survey methodology.) We find that although age (or years of experience) is the best predictor of rank, productivity in terms of publications is a consistently reliable predictor of promotion, except when comparing female assistant to female associate professors. We provide evidence that women are less likely than men to move from assistant professor to associate professor rank. When a woman does achieve associate professor

Vicki L. Hesli is professor of political science at University of Iowa. She can be reached at vick-hesli@uiowa.edu.

Jae Mook Lee is a PhD candidate in the department of political science at the University of Iowa. He can be reached at jaemook-lee@uiowa.edu.

Sara McLaughlin Mitchell is professor of political science at the University of Iowa. She can be reached at sara-mitchell@uiowa.edu. rank, she is as likely as her male colleagues to move on to the rank of full professor.

\section{LITERATURE REVIEW}

According to nearly 40-year-old interviews of chairpersons and heads of departments, the criteria used to judge individuals at promotion time are "teaching, research, and public service to the university" (Katz 1973, 470). Such criteria are now enshrined in faculty handbooks and operations manuals for all colleges and universities. Katz's survey also revealed that "research ability, publication record, and national reputation" were "the most important factors influencing salary and promotion decisions" (470). Doering (1972), however, explored the idea that seniority, years of experience, or simply age is the best predictor of promotion-as one generally cannot advance through the ranks without spending a certain amount of time in each rank (see also Lewis 1967).

Generally findings confirm "that most institutions of higher education 'continue to promote or retain faculty members largely on the basis of publications'" (Woodring 1964, 45 as quoted in Doering 1972, 11). The number of books authored and the number of journal articles published have positive effects on academic career advancement (Ginther and Hayes 1999, 400; Ginther and Kahn 2004, 201; Lewis 1998; Long, Allison, and McGinnis 1993, 718; Over 1993, 318; Tien 2007). Publications have become even more important for promotion than they were in the past given the "increased competition for permanent academic positions" (Ginther and Hayes 2003, 62).

Publications, however, are only one part of faculty productivity. The receipt of grants is also linked to promotion (Fang et al. 2000, 1090; Lee 2002, 703). Whether one's primary work activity is teaching or research influences the duration and probability of promotion (Ginther and Hayes 1999 and 2003; Ginther and Kahn 
2004). Committee service is also an important variable in explaining rank (Katz 1973, 476; Lee 2002, 703).

The type of institution where the faculty member is employed may also affect promotion (Lee 2002, 704). Indeed, Ornstein, Stewart, and Drakich $(2007,19)$ find that "institutional differences in [median time to promotion] are greater than disciplinary differences and much greater than the effect of gender." ${ }^{1}$ Rothgeb and Burger (2009) compare US political science departments and find differences between $\mathrm{BA}$ and $\mathrm{PhD}$ departments in the general standards and procedures used when evaluating tenure. Other work indicates that the likelihood of promotion varies between public and private institutions (Fang et al. 2000, 1087; Ginther and Hayes 1999, 400; Ginther and Hayes 2003, 50; Perna 2005, 284; Tien 2007). Long, Allison, and McGinnis (1993) find that the more prestigious the department of current employment, the lower the odds of promotion, although the effects may be different for women and men (719; see also Ginther and Kahn 2004, 202; Long, Allison, and McGinnis 1993, 797; McDowell and Smith 1992, 78; Morrison, Rudd, and Nerad 2011, 545). Ginther and Kahn (2004, 201) also report that the prestige or tier (rank) of the $\mathrm{PhD}$-granting institution can influence the probability of promotion, as may time-to-degree and the field or area of study (see also Lee 2002, 307; Long, Allison, and McGinnis 1993, 713-714, 719; Morrison et al. 2011, 545; Over 1993, 318). of Earned Doctorates," $40 \%$ of doctoral degrees earned in political science in 2009 went to women. ${ }^{7}$ According to APSA data, the percentage of women among all political science faculty members in the United States in 2009 was $28 \%$. The percentage of female political scientists by academic rank for 2009 was $39 \%$ for assistant professors, $30 \%$ for associate professors and $19 \%$ for full professors. So it appears that at the entry level, women are receiving academic appointments at the same rate as men, but they are not moving up the academic ranks at the same rate as male faculty. ${ }^{8}$

In the 1970 s and 1980 s, an argument was made that not enough $\mathrm{PhDs}$ had yet been granted to women, thus the available pool of qualified female candidates was small, and the number of female tenured faculty simply reflected the smaller available pool. Such an argument is now less convincing given that the proportion of political science doctorate degrees awarded to women has increased from $23 \%$ during $1981-85$, to $27 \%$ between 1986 and 1990 , to $30 \%$ between 1991 and 1995, to $35 \%$ between 1996 and 200o, and to $39 \%$ between 2001 and 2005. ${ }^{9}$ Enough time has passed for more women to have matriculated to full professor. Therefore, the numbers do lead to questions about what is happening to the women.

Numerous studies show that female academics are less likely to be promoted (or take longer to be promoted) than male academics (Allen and Castleman 2001; Fang et al. 2000; Farber 1977, 204; Ginther and Hayes 1999, 400; Ginther and Hayes 2003, 50;

\section{Social capital theories argue that the resources needed to obtain tenure and promotion, such as "information and knowledge about institutional norms, expectations, and opportunities; access to and influence on key decision makers; certification and endorsement of an individual's qualifications; and emotional support and recognition" are less available to women than to men because women lack access to the collegial and social networks that convey critical job-related knowledge.}

In addition to efforts to link productivity, other career information, and institutional characteristics to academic rank, a body of research has focused on the question of whether faculty promotion reveals a gender dimension. Studies have also attempted to determine whether minorities face greater hurdles than their nonminority counterparts. Fueling these debates is evidence of larger numbers of women and racially diverse undergraduate and graduate student populations, yet the proportion of women and minorities among faculty in higher education has not caught up with these trends at the undergraduate and graduate levels.

As of $2009,59 \%$ of the total postbaccalaureate fall enrollment in degree-granting institutions was female. ${ }^{2}$ We compare this to faculty at the same point in time: In fall $2009,47 \%$ of faculty were female. ${ }^{3}$ Among the total 2009 fall enrollment in degree-granting institutions, $33 \%$ were of a nonwhite race or ethnicity. ${ }^{4}$ For the same year, $18 \%$ of college and university faculty were African American, Asian/Pacific Islander, Hispanic, or American Indian/Alaska Native (based on a faculty count that excludes persons whose race/ ethnicity was unknown). 5

Looking specifically at political science (and government), 45\% of bachelor's degrees conferred by degree-granting institutions in 2008-09 were given to women, and 38.5\% of doctoral degrees conferred by degree-granting institutions in 2008-09 were given to women. ${ }^{6}$ According to the National Science Foundation "Survey
Ginther and Kahn 2004, 200; Johnson and Stafford 1974, 892; Kahn 1993, 1995; Katz 1973, 471; Krefting 2003; Long, Allison, and McGinnis 1993; Long and Fox 1995; McDowell, Singell, and Ziliak 1999a, 1999b; McDowell and Smith 1992, 78; Morrison, Rudd, and Nerad 2011; National Science Foundation 2004; Ornstein, Stewart, and Drakich 2007, 15; Perna 2001, 2005; Roos and Gatta 2009; Rudd et al. 2008; Sax et al. 2002; Stewart, Ornstein, and Drakich 2009; Tien 2007, 113; Toutkoushian 1999; Ward 2001). ${ }^{10}$ These findings are well-established, although Jackson and O'Callaghan (2009, 472) argue against the majority in saying that in one-third of the studies that found gender disparities in position attainment and promotion, the differences could be attributed to differences other than gender (i.e., "cohort affect" noted by Morgan 1998). Fewer studies have linked race or ethnicity to a lower probability of promotion, although some studies have done so (Fang et al. 2000, 1090; Ginther and Hayes 2003, 50; Ginther and Kahn 2004, 206; Long and Fox 1995; Toutkoushian 1999). Data from the 1990 reveal that both women and minorities were less likely to be employed in prestigious research universities (Long and Fox 1995, 51).

\section{THEORETICAL PERSPECTIVES}

According to normative theory, "universalism" should characterize science. Universalism requires that the scientific communities' assessment of any contribution to scientific knowledge be 
based on "pre-established impersonal criteria" (Merton [1942] 1973, 270 as described in Long and Fox 1995). "Particularism, in contrast, involves the use of functionally irrelevant characteristics, such as sex and race, as a basis for making claims and gaining rewards in science" (Long and Fox 1995, 46). The question is whether the underrepresentation of women and minorities in the higher academic ranks of US college and university faculty (as described in the above literature review) is the result of universalistic or particularistic criteria.

A variety of theoretical perspectives have attempted to account for different levels of career attainment for women as compared with men. Social capital theories argue that the resources needed to obtain tenure and promotion, such as "information and knowledge about institutional norms, expectations, and opportunities; access to and influence on key decision makers; certification and endorsement of an individual's qualifications; and emotional support and recognition" are less available to women than to men because women lack access to the collegial and social networks that convey critical job-related knowledge (Lin 2001 as quoted in Perna 2005, 28o. See also Milem et al. 2001; O’Leary and Mitchell 1990; Tierney and Bensimon 1996; Yoder 1985). Networks are important at tenure time because they can result in more adulatory outside reference letters. hood of achieving tenure (Kulis and Sicotte 2002; Morrison, Rudd, and Nerad 2011; Rudd et al. 2008). Being married (with or without children) may affect the likelihood of being promoted (Long 2001; Long, Allison, and McGinnis 1993; Perna 2005, 285; Ward 2001, 286), although the effect is likely to be different for men and women (Ginther and Hayes 1999; Kulis and Sicotte 2002; Morrison, Rudd, and Nerad 2011; Wolfinger, Mason, and Goulden 2008). The repercussions of the effects of marriage and children are revealed in 2004 statistics from the National Study of Postsecondary Faculty that show that female faculty members are less likely to be married and much less likely to be both married and have children than their male counterparts. ${ }^{12}$

Critics of social/human capital and life cycle theories argue that these do not adequately explain the lower returns on investment for women and minorities and the segregation of women into lower status occupations (England et al. 1988). Dual or split labor market theories advanced by Feagin and Feagin (1986) argue that institutional barriers that were constructed historically to exclude women and minorities from core or primary sector employment have persisted even after social changes have rendered these barriers illegal (Lee 2002, 697). Conflict theories assume that "dominant groups use their monopoly over resources to maintain their privileges" (Reskin 2003, 2).

\section{Given that figures from the APSA, the National Science Foundation, and the US Department of Education all reveal the underrepresentation of women in higher academic ranks of political science, the Committee on the Status of Women within the APSA felt a responsibility to check whether the norms of universalism or particularism were operating in the process of rank attainment within our discipline.}

Other theories explain differential career progress by focusing on life cycle differences in labor force participation between men and women. A woman who is out of the labor force because of family responsibilities is not acquiring needed human capital (Becker 1993; Farber 1977; Johnson and Stafford 1974; Mincer and Polachek 1974; Zuckerman 1987). Noting additionally that women work fewer hours per year than men when they do work, the effect is that women accumulate fewer years of work experience (Johnson and Stafford 1974, 892). Family responsibilities may cause women to pursue different types of jobs (for example, parttime work) or less demanding work (Becker 1985), and the stress of childcare and household responsibilities may be greater for women than for men (Dey 1994). Women may also be less mobile than men (Rosenfeld and Jones 1987). ${ }^{11}$

Morrison, Rudd, and Nerad $(2011,526)$ observe that because of the need to earn tenure within a set time, "academic careers may be exceptionally demanding during the family formation phase of life" (Acker and Armenti, 2004; Jacobs 2004; Jacobs and Winslow 2004a, 2004b; Over 1993, 318). Researchers have noted that for men, having children has a positive effect on promotion, although for women, children have a negative effect on promotion (Ginther and Hayes 2003, 63-66; Ginther and Kahn 2004; Long, Allison, and McGinnis 1993; Mason and Goulden 2002, 2004; Perna 2005; Ward and Wolf-Wendel 2004). Other studies, however, do not find an independent effect of parenting on the likeli-
More subtle cognitive processes may also operate to favor in-groups and disfavor out-groups (Tajfel and Turner 1986). Rather than experiencing overt discrimination in the workplace, outgroups encounter "consensual status hierarchies" that operate structurally to produce inequality (DiTomaso et al. 2007, 176). Such processes, which perpetuate inequalities, persist not because of conscious efforts, but because individual actions "are complicit with previously established norms" (Bird and Rhoton 2011, 352, see also Rowe 1990). Social psychologists assert that common stereotypes about gender differences in a larger society (a hierarchy of gender status beliefs) are reproduced within organizations such as universities-and important consequences follow, such as differential access to resources and decisions about competence (Roos and Gatta 2009, 179; for a review see Heilman 2001). Because academic judgments of the quality of a colleague's work are inherently subjective, the tendency of evaluators is to fall back on existing schema, stereotypes, and personal biases (Eveline 2004). Sexism in peer review may be a more overt manifestation of such processes (Wenneras and Wold 1997). Other examples of subtle or unconscious discrimination include encouragement of early promotion for men but not for women, more impressive language used to describe the records of men than for women, and promotion to senior professor largely on the basis of departmental administrative needs for men but not for women (Roos and Gatta 2009, 188). 
Table $1 \mathrm{~A}$

Descriptive Statistics for Differences in Means across Ranks (among men only and among women only)

\begin{tabular}{|c|c|c|c|c|c|c|}
\hline & \multicolumn{3}{|c|}{ MEN } & \multicolumn{3}{|c|}{ WOMEN } \\
\hline & Assistant & Associate & Full & Assistant & Associate & Full \\
\hline \multicolumn{7}{|l|}{ Research } \\
\hline Total number of publications & $5.72^{* * *}$ & 13.57 & $32.39 * * *$ & $4.35^{* * *}$ & 9.78 & $24.85^{* * *}$ \\
\hline Frequency of reviewing books & $1.95^{* * *}$ & 3.42 & $4.73^{* * *}$ & $1.38^{* * *}$ & 2.91 & $4.18^{* *}$ \\
\hline Frequency of reviewing articles & $8.52^{* * *}$ & 12.44 & 14.11 & 7.11 & 9.55 & $14.22^{* *}$ \\
\hline Frequency of serving on an editorial boards & $0.18^{* * *}$ & 0.71 & $1.66^{* * *}$ & $0.22^{* * *}$ & 0.78 & $2.16^{* * *}$ \\
\hline Number of external grants awarded & $0.95^{* * *}$ & 2.16 & $4.58^{* * *}$ & 1.96 & 2.07 & $4.28^{* * *}$ \\
\hline Frequency of conference attendance & 5.58 & 4.84 & $3.83^{* *}$ & $5.16^{* *}$ & 4.28 & 4.06 \\
\hline \multicolumn{7}{|l|}{ Teaching } \\
\hline Number of undergraduate courses & 4.70 & 4.37 & 4.13 & 4.38 & 4.69 & $3.71^{* * *}$ \\
\hline Number of graduate courses & 0.89 & 1.13 & 0.94 & 1.13 & 0.94 & 1.18 \\
\hline Number of honors thesis supervised & $0.60 * * *$ & 1.02 & 1.02 & 1.03 & 1.19 & 1.18 \\
\hline Number of independent study supervised & $1.13^{* * *}$ & 2.09 & 2.61 & 1.43 & 1.53 & 1.89 \\
\hline Number of senior project supervised & 1.35 & 1.27 & 1.94 & $1.64^{*}$ & 3.18 & 2.16 \\
\hline Count of overall student advising & $0.56^{* *}$ & 0.74 & 0.77 & $0.49 * * *$ & 0.78 & 0.88 \\
\hline \multicolumn{7}{|l|}{ Service } \\
\hline Frequency of chairing committees & $0.38 * * *$ & 1.10 & $1.57^{* *}$ & $0.49 * * *$ & 1.03 & $1.35^{* *}$ \\
\hline Frequency of committee membership & $2.78 * * *$ & 3.64 & $4.14^{*}$ & $2.82^{* * *}$ & 3.91 & 4.11 \\
\hline \multicolumn{7}{|l|}{ Resources } \\
\hline Count of overall resources & $3.35^{* *}$ & 3.89 & $4.93^{* * *}$ & $3.74^{* *}$ & 4.46 & 4.68 \\
\hline Teaching release & $1.34^{* * *}$ & 3.86 & 4.57 & $2.07^{* * *}$ & 5.16 & 4.23 \\
\hline Current employment department rank & 1.59 & 1.58 & 1.76 & 1.87 & $1.45^{* *}$ & $2.01^{* * *}$ \\
\hline \multicolumn{7}{|l|}{ Background \& demographics } \\
\hline Number of years to complete PhD & 6.42 & 6.29 & $5.90 *$ & 6.92 & 6.31 & 5.80 \\
\hline PhD program rank & 3.59 & 3.79 & $4.00 *$ & 3.77 & 3.74 & $4.09 *$ \\
\hline Number of years in current position & $3.30 * * *$ & 11.34 & $21.09 * * *$ & $3.33^{* * *}$ & 9.93 & $18.67^{* * *}$ \\
\hline Age & $37.87^{* * *}$ & 47.18 & $57.57^{* * *}$ & $37.27^{* * *}$ & 44.78 & $55.16^{* * *}$ \\
\hline Number of children & $0.99 * * *$ & 1.49 & 1.69 & $0.73^{* * *}$ & 1.19 & 1.39 \\
\hline
\end{tabular}

Asterisks in the assistant professor column indicate a significant difference between mean for the assistant professors compared with the associate professors (within gender). Asterisks in the full professor column indicate a significant difference between mean for the full professors compared with the associate professors (within gender).

\section{THE DATA, ANALYSES, AND FINDINGS}

Given that figures from the APSA, the National Science Foundation, and the US Department of Education all reveal the underrepresentation of women in higher academic ranks of political science, the Committee on the Status of Women within the APSA felt a responsibility to check whether the norms of universalism or particularism were operating in the process of rank attainment within our discipline. The committee approached the APSA Council, and the council allocated funds for a survey of all faculty members in departments of political science (and departments of government, public affairs, and international relations) in the United States. We base our analyses on the responses to this survey.

The dependent variable is academic rank. Academic rank has three categories: assistant professor, associate professor, and full professor. We are excluding from these analyses faculty with another rank (e.g., lecturer, instructor) and we selected only those respondents who were in a tenure-track position, which represents the lion's share of respondents (92\%). ${ }^{13}$ Across the entire set of 1,399 respondents to the 2009 APSA survey of political science faculty, $28.3 \%$ were assistant professors, $25.5 \%$ were associate pro- fessors, and $37.2 \%$ were full professors. ${ }^{14}$ For more information on the representativeness of respondents in relation to the target population, see appendix A.

\section{Bivariate Analyses}

The hypotheses that we tested emerge from the literature review above. For example, we expect that a larger number of publications will be associated with a greater likelihood of being at a higher rank. We consider several different measures of research, teaching, and service. We also look at a variety of characteristics of one's current job-as well as background characteristics, such as where one received his or her $\mathrm{PhD}$. Tables $1 \mathrm{~A}$ and $1 \mathrm{~B}$ show the predictor variables that we explored.

The first row of table $1 \mathrm{~A}$ shows the mean for total publications for the different ranks with men and women listed separately. The asterisks in table $1 \mathrm{~A}$ reveal when the differences in means across ranks are statistically significant. Our measure of total productivity counts the number of articles, monographs, chapters, and edited books published to date in one's career. (Appendix B provides coding information for all variables.) The average on the 
Percentage Differences across Ranks (among men and women separately)

\begin{tabular}{|c|c|c|c|c|c|c|}
\hline & \multicolumn{3}{|c|}{ MEN } & \multicolumn{3}{|c|}{ WOMEN } \\
\hline & Assistant & Associate & Full & Assistant & Associate & Full \\
\hline \multicolumn{7}{|l|}{ Research } \\
\hline Co-authorship & $36.7 \%$ & $34.5 \%$ & $35.5 \%$ & $35.8 \%$ & $32.1 \%$ & $32.6 \%$ \\
\hline \multicolumn{7}{|l|}{ Characteristics of current employment } \\
\hline Joint appointment & $4.7 \%$ & $8.9 \%$ & $14.7 \% *$ & $13.7 \%$ & $12.5 \%$ & $18.5 \%$ \\
\hline Currently employed in a $\mathrm{PhD}$ program & $31.4 \%$ & $34.3 \%$ & $34.9 \%$ & $38.8 \% * *$ & $25.0 \%$ & $48.4 \% * * *$ \\
\hline Currently employed in a MA program & $19.2 \%$ & $23.5 \%$ & $16.9 \%$ & $22.3 \%$ & $18.8 \%$ & $19.4 \%$ \\
\hline Currently employed at a private institution & $32.0 \%$ & $38.7 \%$ & $43.3 \%$ & $40.3 \%$ & $46.3 \%$ & $34.4 \%$ \\
\hline American subfield & $37.2 \%$ & $35.8 \%$ & $42.5 \%$ & $36.0 \%$ & $35.0 \%$ & $30.1 \%$ \\
\hline Comparative subfield & $12.2 \%$ & $14.7 \%$ & $16.6 \%$ & $27.3 \%$ & $30.0 \%$ & $17.2 \% * *$ \\
\hline IR subfield & $20.3 \%$ & $20.1 \%$ & $14.0 \%$ & $12.2 \%$ & $12.5 \%$ & $16.1 \%$ \\
\hline Theory subfield & $9.9 \%$ & $9.8 \%$ & $8.6 \%$ & $3.6 \%$ & $6.3 \%$ & $5.4 \%$ \\
\hline More than 7 years in the current position & $2.3 \% * * *$ & $64.2 \% * * *$ & $85 \% * * *$ & $2.9 \% * * *$ & $65.0 \%$ & $92.5 \% * * *$ \\
\hline \multicolumn{7}{|l|}{ Background \& demographics } \\
\hline Undergraduate PS major & $72.7 \%$ & $77.0 \%$ & $69.3 \%$ & $61.9 \%$ & $65.0 \%$ & $61.3 \%$ \\
\hline Private undergraduate school & $43.6 \%$ & $48.0 \%$ & $48.8 \%$ & $47.5 \% * * *$ & $72.5 \%$ & $59.1 \% *$ \\
\hline Minority & 14.7 & 14.6 & 13.6 & $13.8 \%$ & $17.9 \%$ & $14.1 \%$ \\
\hline Married or partnered & $77.9 \%$ & $83.2 \%$ & $92.6 \% * * *$ & $73.9 \% *$ & $83.8 \%$ & $69.6 \%$ \\
\hline Employed partner & $43.0 \%$ & $49.0 \%$ & $52.5 \%$ & $58.7 \%$ & $77.5 \%$ & $54.3 \% * * *$ \\
\hline Citizenship status & $94.2 \%$ & $94.1 \%$ & $96.7 \%$ & $89.9 \% *$ & $96.3 \%$ & $100 \% *$ \\
\hline
\end{tabular}

measure of total productivity for assistant professors is 4.9 , for associates it is 11.4, and for full professors it is 28.5. In terms of the individual components of our total productivity scale, assistant professors had published an average of 3.4 articles, associates had published 6.9 articles, and full professors had published 16.2 articles. Assistants had published on average of o.3 monographs, associates had published 0.73 , and full professors had published 2.3.

Women have a lower average number of article publications at every rank. Women also publish fewer monographs and book chapters than men at the associate and full professor levels. At the assistant professor rank, however, women publish more monographs and an equal number of book chapters compared with men. ${ }^{15}$ For a discussion of reasons behind differential publication rates, see Hesli and Lee (2011).

In terms of other research-related activities, among both men and women, those at higher ranks have more frequently reviewed book and article manuscripts, served on editorial boards, and received external grant awards (table $1 \mathrm{~A}$ ). In contrast, those at higher ranks attend conferences less frequently than those at lower ranks. Teaching loads are similar across ranks: assistants on average teach 4.5 undergraduate courses per year, associates teach 4.4 , and full professors teach 4.0 undergraduate courses per year. Table $1 \mathrm{~A}$ also reveals that one's overall resources tend to increase significantly as one moves up the academic ranks. Notice also that the mean age ranges from 37 to 58 years across the academic ranks.

In table $1 \mathrm{~B}$ we report percentage differences across ranks for the categorical variables used in our analyses. Note, we do not see significant differences across ranks in the proportion whose work is primarily coauthored. Another interesting finding that corresponds with figures reported by the US Department of Education is that women are less likely to be married than men; this is most dramatically apparent at the level of full professor. Several other interesting contrasts are in tables $1 \mathrm{~A}$ and $1 \mathrm{~B}$, but none of these comparisons includes controls for other relevant factors. Thus, we turn to our multivariate analyses.

\section{Multivariate Analyses}

For multivariate analyses, we use logistic regression models to examine the likelihood of being an associate professor as compared with an assistant professor and then to examine the likelihood of being a full professor as compared with an associate professor-based on demographic, institutional, and professional attributes. ${ }^{16}$ Because these dependent variables are dichotomous, binary logit regression is used. These models estimate the logodds of the higher rank occurring relative to the lower rank for each of the independent variables after controlling for the other variables in the model. ${ }^{17}$

We tested the models with a reduced sample where we exclude from the analyses respondents who missed an answer to one or more questions (variables) in the model. We also tested the same models using imputed data and holding the number of cases in the analysis constant at 706 for the comparison between assistant and associate professors and at 823 for the comparison between associate and full professors. The purpose of using imputed estimates of missing responses is to increase the number of observations taken into consideration in the analysis. For example, out of 1,399 survey respondents, 141 did not identify the institution from which they received their PhD. A more significant missing value problem arises with the question: "In what year did you obtain your PhD degree?" Two-hundred and seventy-three people either did not answer or made a mistake when typing in a year. We did not feel comfortable simply dropping these 273 people $(19.5 \%$ of all respondents) from all of our analyses. Therefore, we decided to 
use the multiple imputation Amelia II program to impute estimates of the missing responses on each of the independent variables used in the analysis (Honaker, King, and Blackwell 2011). ${ }^{18}$ The results using multiple imputation are reported in the tables presented here. ${ }^{19}$

We also note that we omitted some variables from the models that we originally considered because repeated preliminary testing revealed that these variables were not statistically significant in the academic rank models (given the other controls in the model). Omitted variables include whether the undergraduate major was political science; the type of undergraduate school (fouryear private liberal arts college, private research university, flagship state university, or other state university); citizenship status; number of independent, honors, and senior projects supervised; frequency of committee membership; and whether one's work is generally sole-authored or co-authored. We excluded a few other variables because they were highly correlated with or represented a concept already included in the model with a different indicator. For example, we did not include the number of years in one's current position; rather we included responses to a question of whether one had been in his or her current position for more than seven years. We did not include frequency of conference attendance nor the number of grants awarded as these are highly correlated with the number of publications. We did not include number of graduate courses taught, as this is directly tied to whether one works in a PhD-granting, MA-granting, or bachelordegree-only granting department. Each of the variables listed in
Model 2A includes demographic and family status variables, plus characteristics of one's graduate training. Note that women have a significantly lower likelihood of being an associate professor (compared with an assistant professor) than do men. Having an employed partner increases the likelihood of being an associate professor. Graduates from higher ranked $\mathrm{PhD}$ programs are more likely to be at the associate level, while more time spent in graduate school works against movement to a higher rank. ${ }^{22}$ Each additional year spent earning the doctoral degree reduces the likelihood of being an associate professor by $14 \%$.

We look next at model $2 \mathrm{~B}$ in table 2. We still predict the likelihood of being an associate professor compared with an assistant, but we now have included characteristics of the job as well as demographic characteristics and information about one's graduate school experience. We continue to consider men and women in the same model. Later we split the sample and separately look at men and women. In this model, the factors that are found to be unrelated to difference in rank are as interesting as those factors that are, so we report both. Among the factors that describe the job, considering male and female professors together, those factors that do not affect the likelihood of being an associate professor are teaching load, ${ }^{23}$ level of resources, whether one has a joint appointment, whether one works in a private versus a public institution, whether one works in a PhD, MA, or bachelors degreegranting department, or whether one works in a highly ranked department. ${ }^{24}$ The factors that are related to an increased likelihood of being an associate professor over an assistant professor

\section{Each additional year spent earning the doctoral degree reduces the likelihood of being an associate professor by $14 \%$.}

this paragraph is included in tables $1 \mathrm{~A}$ and $1 \mathrm{~B}$; readers can see what differences do exist (bivariately) across ranks on these measures.

We attempted to include all relevant variables as identified in the literature in our models. We do this so that when we test hypothesized relationships, such as that between gender and rank, we control for important predictors (such as age and the number of publications). This method of assessing the existence of particularistic criteria in the determination of academic rank is referred to as "sophisticated residualism" (Cole 1979, 29, as quoted in Long and Fox 1995, 54). If sex or race differences remain significant after controlling for relevant variables, we have evidence of particularism. Cotter et al. (2001) use a similar approach in evaluating the "glass ceiling effect," which exists when gender or racial difference cannot be explained by other job-relevant characteristics of the employee.

In interpreting the multivariate analysis, we start with table 2. This table looks only at people in the rank of either assistant or associate professor, and models the likelihood of being an associate professor over an assistant professor. ${ }^{20}$ Because promotion to associate professor occurs usually after five to seven years at the assistant professor rank, we include age as a control variable in all of the models: the older one is, the more likely he or she will be at a higher rank. ${ }^{21}$ Related variables are entered into the logistic regression analysis in blocks to check the contributions of specific categories of predictors. are being more involved in student advising, chairing more committees, and being released from teaching duties. These findings about advising and committee service seem sensible as many departments attempt to protect assistant professors from too much advising and committee service so that they will have more time for their research. Indeed, associate professors advise more and chair more committees than do assistant professors.

For the last model in table 2 (model $2 \mathrm{C}$ ), we add factors that we define as professional characteristics. We see that among men and women together, and with the other controls in the model, subfield specialization is unrelated to the likelihood of being at the associate professor rank; perceptions of departmental influence, frequency of reviewing books or articles, and serving on editorial boards are also not significant. What is related to associate versus assistant professor rank is staying in the same position for at least seven years and research productivity. We included the question of length of time in one's current position to control for the expectation of promotion from the rank of assistant to the rank of associate professor after a certain amount of time passes. We might think of the total number of publications also as an important control variable, as we expect people to be promoted based on their publications. Those at the higher rank have indeed published more articles, chapters, and books. ${ }^{25}$ Note that with the controls for time in position and number of publications in the model $2 \mathrm{C}$, we still see significant differences between men and women in rank. The odds ratio associated with the coefficient for 
Table 2

Predicting Academic Rank: Factors Affecting the Likelihood of Being an Associate Professor
in Contrast with an Assistant Professor (binary logistic models via multiple imputation)

\begin{tabular}{|c|c|c|c|c|c|c|}
\hline \multirow[b]{2}{*}{ INDEPENDENT VARIABLES } & \multicolumn{2}{|c|}{ MODEL 2A } & \multicolumn{2}{|c|}{ MODEL 2B } & \multicolumn{2}{|c|}{ MODEL 2C } \\
\hline & $\begin{array}{l}\text { Coefficient } \\
\text { (Std. Err.) }\end{array}$ & Odds Ratio & $\begin{array}{l}\text { Coefficient } \\
\text { (Std. Err.) }\end{array}$ & Odds Ratio & $\begin{array}{l}\text { Coefficient } \\
\text { (Std. Err.) }\end{array}$ & Odds Ratio \\
\hline Female & $-0.481^{* *}(0.199)$ & 0.618 & $-0.899 * * *(0.237)$ & 0.407 & $-0.720^{* *}(0.282)$ & 0.487 \\
\hline Minority & $-0.051(0.318)$ & 0.951 & $-0.079(0.330)$ & 0.924 & $-0.080(0.458)$ & 0.923 \\
\hline Married or partnered & $0.148(0.306)$ & 1.159 & $-0.143(0.359)$ & 0.867 & $0.166(0.442)$ & 1.181 \\
\hline Number of children & $0.123(0.090)$ & 1.131 & $0.065(0.102)$ & 1.067 & $-0.023(0.119)$ & 0.977 \\
\hline Partner employed & $0.429 *(0.224)$ & 1.536 & $0.630 * *(0.255)$ & 1.878 & $0.308(0.287)$ & 1.361 \\
\hline PhD program rank & $0.116 *(0.071)$ & 1.123 & $0.078(0.084)$ & 1.081 & $0.030(0.100)$ & 1.031 \\
\hline Number of years to complete PhD & $-0.156^{* * *}(0.056)$ & 0.855 & $-0.165^{* * *}(0.062)$ & 0.848 & $-0.125(0.077)$ & 0.882 \\
\hline Age & $0.165^{* * *}(0.018)$ & 1.179 & $0.165^{* * *}(0.018)$ & 1.180 & $0.115^{* * *}(0.022)$ & 1.122 \\
\hline Undergraduate teaching load & & & $0.032(0.057)$ & 1.032 & $0.089(0.065)$ & 1.093 \\
\hline Count of overall student advising & & & $0.590 * * *(0.168)$ & 1.804 & $0.553^{* * *}(0.190)$ & 1.738 \\
\hline Frequency of chairing committees & & & $0.544^{* * *}(0.136)$ & 1.723 & $0.345^{* *}(0.141)$ & 1.413 \\
\hline Joint appointment & & & $0.301(0.372)$ & 1.352 & $0.524(0.455)$ & 1.689 \\
\hline Currently employed at a private institution & & & $0.222(0.241)$ & 1.249 & $0.267(0.276)$ & 1.307 \\
\hline Currently employed in a PhD program & & & $-0.294(0.383)$ & 0.746 & $-0.698(0.507)$ & 0.498 \\
\hline Currently employed in a MA program & & & $-0.382(0.321)$ & 0.683 & $-0.164(0.350)$ & 0.849 \\
\hline Current program ranking & & & $-0.189(0.116)$ & 0.828 & $-0.051(0.153)$ & $(0.950)$ \\
\hline Count of overall resources & & & $0.046(0.048)$ & 1.047 & $-0.044(0.060)$ & 0.957 \\
\hline Teaching release & & & $0.335^{* * *}(0.042)$ & 1.398 & $0.275^{* * *}(0.051)$ & 1.317 \\
\hline American subfield & & & & & $0.415(0.382)$ & 1.514 \\
\hline Comparative subfield & & & & & $0.165(0.428)$ & 1.179 \\
\hline IR subfield & & & & & $-0.069(0.433)$ & 0.933 \\
\hline Theory subfield & & & & & $0.579(0.534)$ & 1.784 \\
\hline More than 7 years in the current position & & & & & $2.502 * * *(0.344)$ & 12.207 \\
\hline Less departmental influence & & & & & $-0.063(0.073)$ & 0.939 \\
\hline Total number of publications & & & & & $0.545^{* * *}(0.179)$ & 1.724 \\
\hline Frequency of reviewing books & & & & & $0.059(0.056)$ & 1.061 \\
\hline Frequency of reviewing articles & & & & & $0.013(0.013)$ & 1.013 \\
\hline Frequency of serving on an editorial boards & & & & & $0.228(0.165)$ & 1.257 \\
\hline Constant & $-6.663^{* * *}(0.867)$ & 0.001 & $-7.796 * * *(0.968)$ & 0.0004 & $-7.645^{* * *}(1.283)$ & 0.0005 \\
\hline $\mathrm{N}$ & 706 & & 706 & & 706 & \\
\hline $\mathrm{N}$ of simulations & 1000 & & 1000 & & 1000 & \\
\hline
\end{tabular}

Note. ${ }^{* * *} p<0.01,{ }^{* *} p<0.05,{ }^{*} p<0.1$

women in model $2 \mathrm{C}$ reveals that the likelihood of a woman being at the associate professor rank is $51 \%$ less than it is for a man. Stated differently: the chance of a female faculty member being at the associate professor rank is only $49 \%$ of the chance that a male faculty member is at associate rank.

Table 3 looks only at people in the rank of either associate or full professor and models the likelihood of being a full professor in contrast to an associate professor. A key finding here is that being a woman does not affect the likelihood of being at one rank rather than another. Besides the control for age, the only variable from the first set (model $3 \mathrm{~A})$ that influences the likelihood of being a full professor is the length of time that it took the candidate to complete his or her doctoral degree. Again, spending too much time in graduate school appears to hinder later promotion through the ranks. ${ }^{26}$

We look at model $3 \mathrm{~B}$ to evaluate whether characteristics of the job are significant predictors of rank when professional characteristics are not yet considered. We see that the likelihood of being at the rank of full professor is higher with more frequent committee service, less likely when working in an MA program, more likely in more highly ranked departments, and more likely with more resources and release from teaching. ${ }^{27}$ Each of these 
Table 3

Predicting Academic Rank: Associate Professors Compared with Full Professors (binary logistic models via multiple imputation)

\begin{tabular}{|c|c|c|c|c|c|c|}
\hline \multirow[b]{2}{*}{ INDEPENDENT VARIABLES } & \multicolumn{2}{|c|}{ MODEL 3A } & \multicolumn{2}{|c|}{ MODEL 3B } & \multicolumn{2}{|c|}{ MODEL 3C } \\
\hline & $\begin{array}{l}\text { Coefficient } \\
\text { (Std. Err.) }\end{array}$ & Odds Ratio & $\begin{array}{l}\text { Coefficient } \\
\text { (Std. Err.) }\end{array}$ & Odds Ratio & $\begin{array}{l}\text { Coefficient } \\
\text { (Std. Err.) }\end{array}$ & Odds Ratio \\
\hline Female & $0.133(0.215)$ & 1.142 & $0.135(0.225)$ & 1.145 & $0.209(0.237)$ & 1.232 \\
\hline Minority & $-0.220(0.270)$ & 0.803 & $-0.244(0.270)$ & 0.783 & $-0.287(0.290)$ & 0.751 \\
\hline Married or partnered & $0.373(0.321)$ & 1.452 & $0.309(0.333)$ & 1.362 & $0.429(0.355)$ & 1.536 \\
\hline Number of children & $0.004(0.076)$ & 1.004 & $-0.036(0.078)$ & 0.964 & $-0.047(0.080)$ & 0.954 \\
\hline Partner employed & $-0.134(0.229)$ & 0.875 & $-0.175(0.240)$ & 0.840 & $-0.232(0.253)$ & 0.793 \\
\hline PhD program rank & $0.096(0.067)$ & 1.101 & $0.020(0.073)$ & 1.020 & $-0.012(0.078)$ & 0.989 \\
\hline Number of years to complete PhD & $-0.087^{* *}(0.040)$ & 0.916 & $-0.082^{* *}(0.040)$ & 0.921 & $-0.051(0.041)$ & 0.951 \\
\hline Age & $0.132^{* * *}(0.011)$ & 1.141 & $0.139 * * *(0.011)$ & 1.149 & $0.136^{* * *}(0.012)$ & 1.146 \\
\hline Undergraduate teaching load & & & $-0.040(0.048)$ & 0.961 & $-0.014(0.050)$ & 0.987 \\
\hline Amount of student advising & & & $-0.044(0.135)$ & 0.957 & $-0.076(0.142)$ & 0.927 \\
\hline Frequency of chairing committees & & & $0.151^{* *}(0.072)$ & 1.163 & $0.115(0.075)$ & 1.122 \\
\hline Joint appointment & & & $0.016(0.273)$ & 1.016 & $-0.050(0.292)$ & 0.951 \\
\hline Currently employed at a private institution & & & $0.204(0.207)$ & 1.226 & $0.324(0.220)$ & 1.383 \\
\hline Currently employed in a PhD program & & & $-0.386(0.313)$ & 0.680 & $-0.566 *(0.338)$ & 0.568 \\
\hline Currently employed in a MA program & & & $-0.478 *(0.263)$ & 0.620 & $-0.427(0.271)$ & 0.653 \\
\hline Current program ranking & & & $0.171^{*}(0.091)$ & 1.187 & $0.122(0.100)$ & 1.130 \\
\hline Count of overall resources & & & $0.073 * *(0.033)$ & 1.075 & $0.015(0.036)$ & 1.015 \\
\hline Teaching release & & & $0.037 *(0.020)$ & 1.038 & $0.033(0.021)$ & 1.033 \\
\hline American subfield & & & & & $0.203(0.257)$ & 1.225 \\
\hline Comparative subfield & & & & & $-0.104(0.309)$ & 0.902 \\
\hline IR subfield & & & & & $-0.381(0.316)$ & 0.684 \\
\hline Theory subfield & & & & & $-0.094(0.381)$ & 0.910 \\
\hline More than 7 years in the current position & & & & & $0.371^{*}(0.224)$ & 1.448 \\
\hline Less departmental influence & & & & & $-0.095 *(0.052)$ & 0.910 \\
\hline Total number of publications & & & & & $0.301^{* * *}(0.111)$ & 1.351 \\
\hline Frequency of reviewing books & & & & & $0.031(0.030)$ & 1.031 \\
\hline Frequency of reviewing articles & & & & & $0.005(0.007)$ & 1.005 \\
\hline Frequency of serving on an editorial boards & & & & & $0.302 * * *(0.090)$ & 1.352 \\
\hline Constant & $-6.524 * * *(0.666)$ & 0.002 & $-7.034^{* * *}(0.828)$ & 0.0009 & $-7.898(0.910)$ & 0.0004 \\
\hline N & 823 & & 823 & & 823 & \\
\hline $\mathrm{N}$ of simulations & 1000 & & 1000 & & 1000 & \\
\hline
\end{tabular}

Note. ${ }^{* *} p<0.01,{ }^{* *} p<0.05,{ }^{*} p<0.1$

significant factors from the second set of variables in model $3 \mathrm{~B}$, however, loses their significance when the professional variables are added to the equation (model ${ }_{3} \mathrm{C}$ ).

According to model ${ }_{3} \mathrm{C}$ (table 3 ), which includes all possible controls, the likelihood of being a full professor (over an associate professor) is lower in a $\mathrm{PhD}$-granting program (rather than a MA program or a bachelor's program [the excluded category]). In addition, the greater one's perceived influence in department decision making, the greater the likelihood that one is a full professor. As expected, more publications lead to a greater likelihood of being a full professor. More frequent service on editorial boards also cor- relates with a greater likelihood of being a full professor. ${ }^{28} \mathrm{We}$ note the significance of the coefficients associated with age and having been in the same position for at least seven years; we think of these more as control variables as we expect that a certain amount of time must be spent at the associate-professor rank before one can advance to the full-professor rank.

Hypotheses Tests with a Split Sample: Men and Women Examined Separately. Given the importance of gender in table 2, we divide the sample and test the models separately on tenure track women only and on tenure track men only. These tests are found in tables 4 and 5 . Using this information, we explore whether the 
Table 4

Predicting Academic Rank: Associate Professor Compared with Assistant Professor (spilt sample)

\begin{tabular}{|c|c|c|c|c|c|c|c|c|}
\hline \multirow[b]{3}{*}{ INDEPENDENT VARIABLES } & \multicolumn{2}{|l|}{ MODEL 4A } & \multicolumn{2}{|l|}{ MODEL 4B } & \multicolumn{2}{|c|}{ MODEL 4C } & \multicolumn{2}{|c|}{ MODEL 4D } \\
\hline & \multicolumn{2}{|l|}{ Men Only } & \multicolumn{2}{|c|}{ Women Only } & \multicolumn{2}{|c|}{ Men Only } & \multicolumn{2}{|c|}{ Women Only } \\
\hline & $\begin{array}{l}\text { Coef. } \\
\text { (Std. Err.) }\end{array}$ & $\begin{array}{l}\text { Odds } \\
\text { Ratio }\end{array}$ & $\begin{array}{l}\text { Coef. } \\
\text { (Std. Err.) }\end{array}$ & $\begin{array}{l}\text { Odds } \\
\text { Ratio }\end{array}$ & $\begin{array}{l}\text { Coef. } \\
\text { (Std. Err.) }\end{array}$ & $\begin{array}{l}\text { Odds } \\
\text { Ratio }\end{array}$ & $\begin{array}{l}\text { Coef. } \\
\text { (Std. Err.) }\end{array}$ & $\begin{array}{l}\text { Odds } \\
\text { Ratio }\end{array}$ \\
\hline Minority & $-0.701 *(0.401)$ & 0.496 & $1.105(0.651)$ & 3.018 & $-0.602(0.546)$ & 0.548 & $0.632(0.927)$ & 1.880 \\
\hline Married or partnered & $-0.224(0.447)$ & 0.800 & $-0.417(0.975)$ & 0.659 & $0.007(0.509)$ & 1.007 & $-0.025(1.305)$ & 0.976 \\
\hline Number of children & $0.079(0.124)$ & 1.082 & $-0.069(0.231)$ & 0.934 & $0.038(0.149)$ & 1.039 & $-0.300(0.338)$ & 0.741 \\
\hline Partner employed & $0.219(0.372)$ & 1.245 & $1.916(1.046)$ & 6.795 & $-0.082(0.364)$ & 0.921 & $1.946 * *(0.911)$ & 7.000 \\
\hline PhD program rank & $0.077(0.117)$ & 1.080 & $0.030(0.162)$ & 1.030 & $0.055(0.138)$ & 1.057 & $-0.016(0.276)$ & 0.985 \\
\hline Number of years to complete PhD & $-0.139(0.087)$ & 0.870 & $-0.266^{* *}(0.119)$ & 0.766 & $-0.088(0.110)$ & 0.915 & $-0.288(0.216)$ & 0.750 \\
\hline Age & $0.170 * * *(0.024)$ & 1.185 & $0.207^{* * *}(0.055)$ & 1.229 & $0.110 * * *(0.030)$ & 1.117 & $0.162^{* * *}(0.052)$ & 1.176 \\
\hline Undergraduate teaching load & $0.028(0.078)$ & 1.029 & $0.096(0.120)$ & 1.101 & $0.116(0.102)$ & 1.123 & $0.174(0.166)$ & 1.190 \\
\hline Count of overall student advising & $0.515^{* *}(0.213)$ & 1.674 & $1.017 * *(0.400)$ & 2.764 & $0.507^{* *}(0.235)$ & 1.660 & $1.086 *(0.558)$ & 2.963 \\
\hline Frequency of chairing committees & $0.818 * * *(0.206)$ & 2.265 & $0.288 * *(0.146)$ & 1.334 & $0.755^{* * *}(0.243)$ & 2.127 & $0.187(0.191)$ & 1.206 \\
\hline Joint appointment & $0.355(0.561)$ & 1.426 & 0.705 (0.714) & 2.024 & $0.543(0.640)$ & 1.722 & 1.503 (1.068) & 4.493 \\
\hline $\begin{array}{l}\text { Currently employed at a private } \\
\text { institution }\end{array}$ & $0.310(0.324)$ & 1.363 & $-0.084(0.456)$ & 0.919 & $0.389(0.386)$ & 1.476 & $0.174(0.651)$ & 1.190 \\
\hline Currently employed in a PhD program & $-0.132(0.482)$ & 0.876 & $-0.656(0.724)$ & 0.519 & $-0.746(0.632)$ & 0.474 & $-0.640(0.966)$ & 0.528 \\
\hline Currently employed in a MA program & $-0.233(0.406)$ & 0.792 & $-0.723(0.578)$ & 0.485 & $-0.047(0.465)$ & 0.954 & $-0.553(0.841)$ & 0.575 \\
\hline Current program ranking & $-0.025(0.152)$ & 0.975 & $-0.499 *(0.263)$ & 0.607 & $0.158(0.204)$ & 1.171 & $-0.608(0.386)$ & 0.544 \\
\hline Count of overall resources & $0.061(0.064)$ & 1.062 & $0.063(0.119)$ & 1.065 & $-0.016(0.083)$ & 0.984 & $0.003(0.139)$ & 1.003 \\
\hline Teaching release & $0.340 * * *(0.060)$ & 1.405 & $0.390 * * *(0.078)$ & 1.477 & $0.251^{* * *}(0.070)$ & 1.285 & $0.454^{* * *}(0.104)$ & 1.574 \\
\hline American subfield & & & & & $0.155(0.492)$ & 1.168 & $1.170(0.848)$ & 3.223 \\
\hline Comparative subfield & & & & & $-0.176(0.601)$ & 0.838 & $1.141(1.042)$ & 3.130 \\
\hline IR subfield & & & & & $-0.212(0.550)$ & 0.809 & 0.919 (1.214) & 2.507 \\
\hline Theory subfield & & & & & $0.010(0.701)$ & 1.010 & $1.907(1.412)$ & 6.732 \\
\hline $\begin{array}{l}\text { More than } 7 \text { years in the current } \\
\text { position }\end{array}$ & & & & & $2.581^{* * *}(0.477)$ & 13.214 & $3.188^{* * *}(0.833)$ & 23.239 \\
\hline Less departmental influence & & & & & $0.030(0.088)$ & 1.030 & $-0.430 *(0.221)$ & 0.651 \\
\hline Total number of publications & & & & & $0.713 * * *(0.230)$ & 2.041 & $0.303(0.453)$ & 1.353 \\
\hline Frequency of reviewing books & & & & & $0.038(0.066)$ & 1.038 & $0.211 *(0.117)$ & 1.235 \\
\hline Frequency of reviewing articles & & & & & $0.004(0.017)$ & 1.004 & $0.019(0.046)$ & 1.019 \\
\hline $\begin{array}{l}\text { Frequency of serving on an } \\
\text { editorial boards }\end{array}$ & & & & & $0.356(0.234)$ & 1.427 & $-0.1289(0.344)$ & 0.880 \\
\hline Constant & $-8.404 * * *(1.330)$ & 0.0002 & $-10.103 * *(3.329)$ & 0.0004 & $-8.665^{* * *}(1.989)$ & 0.0002 & $-9.719 *(4.434)$ & 0.0006 \\
\hline $\mathrm{N}$ & 442 & & 264 & & 442 & & 264 & \\
\hline $\mathrm{N}$ of simulations & 1000 & & 1000 & & 1000 & & 1000 & \\
\hline
\end{tabular}

Note. ${ }^{* *} p<0.01,{ }^{* *} p<0.05,{ }^{*} p<0.1$

relationships between the predictors of promotion to associate professor or to full professor vary between men and women. Table 4 presents tests of a logit model of the probability of being in the associate professor category over the assistant professor category using a split sample. Let us compare model 4A (for men) with model $4 \mathrm{~B}$ (for women). These two models include all predictor variables except the professional variables. We remind readers that these models include a control for age, which is the best predictor of academic rank. We find that the following variables are not predictive of rank for either men or women: being married or partnered, number of children, whether one's partner is employed, and the rank of the program where one received his or her doctoral degree. ${ }^{29}$ In other words, when we consider men and women separately, the likelihood of being tenured does not improve for either men or women based on whether one was trained by a top-ranked department.

With regard to characteristics of the job, the following variables do not differentiate between the likelihood of being an assistant or an associate professor: teaching load, having a joint appointment, working at a private school, being in a $\mathrm{PhD}$ or an MA program, and amount of resources. ${ }^{30}$ Noteworthy is that higher levels of advising and more frequent committee service (as chair) are significantly associated with being in the associate professor category for both men and women. Again, we observe that many departments make a concerted effort to reduce the amount of advising and committee service among assistant professors, so we are not arguing that more of either one will help one to become an associate professor. What 


\section{Table 5}

\section{Predicting Academic Rank: Associate Professors Compared with Full Professors (Split sample)}

\begin{tabular}{|c|c|c|c|c|c|c|c|c|}
\hline \multirow[b]{3}{*}{ INDEPENDENT VARIABLES } & \multicolumn{2}{|c|}{ MODEL 5A } & \multicolumn{2}{|c|}{ MODEL 5B } & \multicolumn{2}{|c|}{ MODEL 5C } & \multicolumn{2}{|c|}{ MODEL 5D } \\
\hline & \multicolumn{2}{|c|}{ Men Only } & \multicolumn{2}{|c|}{ Women Only } & \multicolumn{2}{|l|}{ Men Only } & \multicolumn{2}{|c|}{ Women Only } \\
\hline & $\begin{array}{c}\text { Coef. } \\
\text { (Std. Err.) }\end{array}$ & $\begin{array}{l}\text { Odds } \\
\text { Ratio }\end{array}$ & $\begin{array}{c}\text { Coef. } \\
\text { (Std. Err.) }\end{array}$ & $\begin{array}{l}\text { Odds } \\
\text { Ratio }\end{array}$ & $\begin{array}{c}\text { Coef. } \\
\text { (Std. Err.) }\end{array}$ & $\begin{array}{l}\text { Odds } \\
\text { Ratio }\end{array}$ & $\begin{array}{c}\text { Coef. } \\
\text { (Std. Err.) }\end{array}$ & $\begin{array}{l}\text { Odds } \\
\text { Ratio }\end{array}$ \\
\hline Minority & $-0.523 *(0.310)$ & 0.593 & $0.240(0.495)$ & 1.271 & $-0.660 *(0.348)$ & 0.517 & $0.369(0.552)$ & 1.446 \\
\hline Married or partnered & $0.549(0.403)$ & 1.732 & $0.139(0.762)$ & 1.149 & $0.766^{*}(0.437)$ & 2.152 & $0.273(0.887)$ & 1.314 \\
\hline Number of children & $-0.083(0.094)$ & 0.920 & $0.104(0.190)$ & 1.110 & $-0.083(0.097)$ & 0.921 & $-0.006(0.224)$ & 0.994 \\
\hline Employed partner & $-0.063(0.306)$ & 0.939 & $-0.532(0.640)$ & 0.588 & $-0.173(0.331)$ & 0.841 & $-0.529(0.780)$ & 0.589 \\
\hline PhD program rank & $0.003(0.105)$ & 1.003 & $0.054(0.158)$ & 1.056 & $-0.038(0.110)$ & 0.963 & $0.012(0.182)$ & 1.013 \\
\hline Number of years to complete PhD & $-0.102^{* *}(0.049)$ & 0.903 & $0.001(0.089)$ & 1.001 & $-0.075(0.048)$ & 0.928 & $0.063(0.103)$ & 1.065 \\
\hline Age & $0.141^{* * *}(0.013)$ & 1.151 & $0.142 * * *(0.026)$ & 1.152 & $0.139 * * *(0.014)$ & 1.149 & $0.148 * * *(0.033)$ & 1.159 \\
\hline Undergraduate teaching load & $-0.037(0.059)$ & 0.964 & $-0.096(0.093)$ & 0.909 & $-0.016(0.062)$ & 0.984 & $-0.024(0.095)$ & 0.976 \\
\hline Count of overall student advising & $-0.033(0.172)$ & 0.968 & $0.114(0.366)$ & 1.120 & $-0.034(0.181)$ & 0.966 & $-0.077(0.387)$ & 0.926 \\
\hline Frequency of chairing committees & $0.170 *(0.091)$ & 1.186 & $0.091(0.170)$ & 1.096 & $0.117(0.094)$ & 1.124 & $0.094(0.196)$ & 1.099 \\
\hline Joint appointment & $0.107(0.357)$ & 1.113 & $-0.213(0.506)$ & 0.809 & $-0.077(0.380)$ & 0.926 & $-0.150(0.600)$ & 0.860 \\
\hline $\begin{array}{l}\text { Currently employed at a private } \\
\text { institution }\end{array}$ & $0.248(0.245)$ & 1.281 & $0.265(0.448)$ & 1.304 & $0.320(0.262)$ & 1.377 & $0.528(0.517)$ & 1.696 \\
\hline Currently employed in a PhD program & $-0.757^{*}(0.391)$ & 0.469 & $0.474(0.606)$ & 1.606 & $-0.982^{* *}(0.434)$ & 0.375 & $0.682(0.737)$ & 1.978 \\
\hline Currently employed in a MA program & $-0.753^{*}(0.332)$ & 0.471 & $0.322(0.581)$ & 1.380 & $-0.745^{* *}(0.347)$ & 0.475 & $0.578(0.699)$ & 1.783 \\
\hline Current program ranking & $0.167(0.111)$ & 1.182 & $0.109(0.194)$ & 1.115 & $0.120(0.120)$ & 1.127 & $0.060(0.232)$ & 1.062 \\
\hline Count of overall resources & $0.099 * *(0.041)$ & 1.104 & $0.004(0.082)$ & 1.004 & $0.061(0.044)$ & 1.063 & $-0.163(0.106)$ & 0.850 \\
\hline Teaching release & $0.044^{*}(0.024)$ & 1.045 & $0.013(0.047)$ & 1.013 & $0.042^{*}(0.025)$ & 1.043 & $0.016(0.057)$ & 1.017 \\
\hline American subfield & & & & & $0.340(0.328)$ & 1.405 & $-0.293(0.591)$ & 0.746 \\
\hline Comparative subfield & & & & & $0.056(0.415)$ & 1.058 & $-0.617(0.619)$ & 0.540 \\
\hline IR subfield & & & & & $-0.413(0.393)$ & 0.661 & $-0.445(0.673)$ & 0.641 \\
\hline Theory subfield & & & & & $0.027(0.441)$ & 1.027 & $-0.776(1.005)$ & 0.460 \\
\hline $\begin{array}{l}\text { More than } 7 \text { years in the current } \\
\text { position }\end{array}$ & & & & & $0.181(0.271)$ & 1.199 & $0.974 *(0.557)$ & 2.649 \\
\hline Less departmental influence & & & & & $-0.113(0.071)$ & 0.893 & $-0.013(0.123)$ & 0.988 \\
\hline Total number of publications & & & & & $0.269 *(0.139)$ & 1.309 & $0.415^{*}(0.248)$ & 1.514 \\
\hline Frequency of reviewing books & & & & & $0.019(0.039)$ & 1.019 & $0.055(0.064)$ & 1.057 \\
\hline Frequency of reviewing articles & & & & & $0.003(0.009)$ & 1.003 & $0.016(0.018)$ & 1.016 \\
\hline $\begin{array}{l}\text { Frequency of serving on an } \\
\text { editorial boards }\end{array}$ & & & & & $0.359 * * *(0.113)$ & 1.432 & $0.235(0.178)$ & 1.265 \\
\hline Constant & $-7.117 * * *(0.958)$ & 0.0008 & $-7.416 * * *(1.723)$ & 0.0006 & $-7.829 * * *(1.082)$ & 0.0004 & $-9.502^{* * *}(2.132)$ & 0.0007 \\
\hline$N$ & 595 & & 228 & & 595 & & 228 & \\
\hline $\mathrm{N}$ of simulations & 1000 & & 1000 & & 1000 & & 1000 & \\
\hline
\end{tabular}

Note. ${ }^{* * *} p<0.01,{ }^{* *} p<0.05,{ }^{*} p<0.1$

we are saying is that the job is different with regard to advising and committee service when one is no longer an assistant professor. ${ }^{31}$ Another finding that holds for both men and women concerns teaching release: the more courses from which one has been released, the more likely one is to be in the associate professor category.

Some variables' effects are different for female faculty as compared to male faculty. ${ }^{32}$ For example, minority men are less likely than nonminority men to be in the associate professor rank compared with assistant professor. Among female faculty, taking more time to complete the $\mathrm{PhD}$ reduces the likelihood of being an associate professor over an assistant professor. Another difference between men and women that we see in this set is that among women only, a lower ranking of one's current department is asso- ciated with a greater likelihood of being an associate professor (rather than an assistant).

To finish our analysis of the factors related to the likelihood of being an associate professor over an assistant professor, we look at models ${ }_{4} \mathrm{C}$ (for men) and ${ }_{4} \mathrm{D}$ (for women) in table 4. These models include the professional characteristics of the faculty members. The difference that we observe between men and women is that perceptions of departmental influence and frequency of reviewing a book are related to the associate professor rank for women, but not for men. ${ }^{33}$ This means that with the controls in models ${ }_{4} \mathrm{C}$ and ${ }_{4} \mathrm{D}$, only female associate professors have reviewed more books and report more influence over department decision-making than female assistant professors. 
Rather shockingly, the total number of publications is not related to rank (assistant to associate) for women, although the number of publications is significantly related to the rank of men. This is the only place where we find academic rank to be unrelated to publication productivity. ${ }^{34}$ We need to highlight this substantively significant and uncomfortable finding . The lack of significance associated with the coefficient for total publications in the model for women (model $4 \mathrm{D}$ ) means that no discernible relationship exists among women between number of publications and the likelihood of being in the rank of associate professor (over the rank of assistant professor)-which is troubling because the number of publications should be a predictor of rank. Publications, along with teaching and service, are supposed to be the criteria used to evaluate candidates at promotion time. ${ }^{35}$ We remind readers that differences in the likelihood ratios that are significant for women and men suggest that the predictors of rank are different for men than for women. We return to this finding later in our discussion.

Now, we turn to differences between the rank of associate and full professor based on separate analyses for men and women (table 5). According to model ${ }_{5} \mathrm{~B}$, none of the demographic or graduate program variables are useful for differentiating between associate and full-professor rank among women (except, of course, age). Among men (model $5 \mathrm{~A}$ ), however, minorities are less well represented at the full-professor rank, and taking longer to complete the doctoral degree negatively affects the likelihood of being in the full-professor rank. In addition, among women, none of the characteristics of one's current job (the second set of variables) are different for associate as compared with full professors. Among men, however, full professors are more likely to chair more committees, and less likely to be employed in a $\mathrm{PhD}$ or MA department. Among men only, those with more resources and course releases are more likely to be full professors than associate professors. professors have reviewed more books and have served on more editorial boards than have female and male associate professors respectively (table $1 \mathrm{~A}$ ).

\section{DISCUSSION}

The analyses presented here raise some serious issues. One concern is the lower likelihood of women as compared to men of being in the associate as compared to the assistant professor rank. This means a significant advantage for men in the probability of becoming an associate professor, which usually includes tenure. Despite holding constant a variety of relevant factors such as age and number of publications, this difference between men and women in rank attainment remains significant. Stated another way, despite detailed controls for personal attributes, institutional characteristics, and professional qualifications, women are underrepresented among the tenured members of the political science profession. The evidence of the lower likelihood of women being at the associate professor rank presented here, as well as the APSA and NSF figures for numbers of women within different academic ranks of political science, provide strong evidence that women are indeed falling out of the profession around tenure time. This finding may actually represent deterioration within our profession. Data gathered around the end of the 2oth century indicated that women were gaining tenure at rates relatively similar to men (Hesli and Burrell 1995; McBride Stetson et al. 1990; Van Assendelft, Gunther-Canada, and Dolan 2001).

In contrast to our finding that female faculty have a lower likelihood of being at the rank of associate professor, we find no significant difference between men and women in the likelihood of achieving full-professor status after having become an associate professor. Those women who survive the tenure process are as likely as men (given relevant controls) to move up the academic ladder to full professor. This finding fits comfortably with the notion that "upon entering the rank of associate professor, men

\section{Another finding that holds for both men and women concerns teaching release: the more courses from which one has been released, the more likely one is to be in the associate professor category as compared with the assistant professor category.}

Turning to the professional variables (models $5 \mathrm{C}$ and $5^{\mathrm{D}}$ ), subfield is again unrelated to being in a higher rank for both men and women. A larger number of total publications is related to full-professor rank for both men and women. Interestingly, the size of the effect of the number of publications on promotion to full professor is larger for women than for men. Among men only, more frequent service on editorial boards is related to the higher rank. To summarize, among women, it appears that the only factor that differentiates between associate and full professors is total publications (plus our controls for age and time in position). ${ }^{36}$ Thus, standard predictors of full-professor rank, such as the type of institution where one is employed, appear to work better to explain promotion for men than for women. Here, readers should note that many differences across ranks are apparent in a bivariate sense (see tables $1 \mathrm{~A}$ and $1 \mathrm{~B}$ ). Without controls for such important predictors as age and number of years in one's current position, we do know that both female and male full and women are more similar than they were when entering the rank of assistant professor" (Long, Allison, and McGinnis 1993, 715). ${ }^{37}$ This conclusion also indicates that with regard to promotion to full professor, the political science profession has not changed that much during the last decade and a half. Studying the political science profession in the mid-1990s, Hesli and Burrell (1995) reported that when women apply for full professorship they are likely to be promoted at the same rates as men (103). Remarkably, our findings about the lower likelihood of women gaining tenure-but that female survivors of the tenure process fair similarly to men in later promotion decisions-appear similar to those published more than 30 years ago: Farber $(1977,203-4)$ found that among younger age cohorts, "females received significantly fewer rank promotions"-but that if a woman can continue in academia beyond the younger cohort, through the middle and into the older age cohort, she will receive rank promotions on par with her male counterparts. 
Contrary to expectations based on life-cycle theories, being married or partnered and/or the number of children does not generally affect promotion through the ranks. ${ }^{3}$ The number of children is not significantly different when full professors are compared with associate professors. The number of children is positively correlated with age, so we cannot fully separate the effects of these two variables on promotion to associate professor. We note that other recent research has revealed differential patterns for men and women: "neither parenting nor marriage significantly affects the rate of promotion to tenure for women. However, for men, being in a marriage to a spouse without a professional degree significantly improves the odds of transitioning to tenure" (Morrison, Rudd, and Nerad 2011, 545). Morrison and colleagues $(2011,550)$ mention the possibility of a selection effect: "only women who feel secure enough in their career choose to have children and therefore advance at a competitive rate." We need to be careful in interpreting findings about the effects of children on career advancement, as women with heavy family responsibilities may have already left academia. Our panel study (referenced later) will allow us to address directly the possibility of such a phenomenon.
Rather surprisingly, we see little difference in undergraduate teaching loads across the ranks. We are wary of collinearity associated with this variable. The number of undergraduate courses taught tends to be lower in higher ranked departments. Similarly, the more undergraduate courses taught, the fewer overall resources. More teaching at the undergraduate level is also correlated with fewer total publications and a lower frequency of reviewing articles.

We do see significantly higher levels of advising at the associate and full-professor levels as compared with assistant professors. In addition, although we often think of teaching release as something offered to assistant professors so that they can concentrate on the research, this survey reveals that the higher one's rank attainment, the more likely one is to be released from teaching responsibilities. More resources are associated with higher ranked departments of current employment.

We also note that among men, being a minority decreases the odds of being a full professor over an associate professor. This finding remains significant even with all the controls included in our most comprehensive predictive model. A possible explanation for this finding comes from Tierney and Bensimon (1996) who conclude, "institutional structures, policies, and practices

\section{Another critical finding that we note with some consternation is that among women, the probability of being an associate professor over an assistant professor is unrelated (given other controls) to the total number of publications. This confirms that the promotion process at this level involves different dynamics for men as compared with women.}

Another critical finding that we note with some consternation is that among women, the probability of being an associate professor over an assistant professor is unrelated (given other controls) to the total number of publications (model $4 \mathrm{D}$ ). This confirms that the promotion process at this level involves different dynamics for men as compared with women. In all of our other models, we found, as we would expect, that the total number of publications is an important predictor for both men and women of the likelihood of being promoted from assistant to associate professor rank and from associate to full professor. Thus, the mantra of "publish or perish" is substantiated by this research with the notable exception of the movement of women from assistant to associate professor rank. The obvious question is this: why is it that the number of publications for women has no significant effect on their promotion from assistant to associate professor?

Some other findings that tie into the existing literature include the lack of significant differences in rank attainment based on the quality of the graduate program. It is often assumed that receipt of a doctoral degree from a highly ranked department improves one's career prospects. However, we find that PhD-program quality tends not to be related to the academic rank achieved. We do observe a positive correlation between $\mathrm{PhD}$-program rank and current employment in a PhD-granting department. Also, the higher the ranking of the department where one received his or her doctorate, the higher the ranking of the department where one is currently employed. We find that those who take longer to earn their $\mathrm{PhD}$ are less likely to attain higher rank. that are intended to be gender- and race-neutral may be creating a working environment that is unsupportive, patronizing and even hostile" (as quoted in Perna 2001, 563). A limitation of this study is that because the number of self-identified members of a minority ethnic or racial group is so small, we cannot reasonably study differences between, for example, African Americans, Asian Americans, or Hispanic Americans. In fact, our aggregation may mask differences among these groups. In addition, as Ginther and Hayes $(2003,68)$ argue, we cannot conclude that discrimination is the underlying cause of gender or identity differences in promotion unless we are sure that we have controlled for all relevant factors - and we cannot be sure of this. For example, we have not controlled for quality of teaching - if indeed this can be reliably measured. The analyses presented here are also limited to cross-sectional data, which we have used to study a longitudinal promotion process. An implication is that the variables describe characteristics of respondents at one time point. To remedy this, we have collected the data for the first stage of a panel study and will report the results of longitudinal research after the second stage of the panel study is conducted. We also acknowledge the possibility of error in self-reports especially on retrospective measures in surveys. We believe, however, that the benefits of survey research outweigh the problems.

Given the lack of statistical significance for many predictors of higher academic rank among women in our multivariate models, in a future article, we will delve more deeply into the "climate" evaluations provided by the survey respondents. The "micro" climate of each scholar's home department could affect promotion 
decisions. "Climate" is a factor when women perceive or experience a climate different from the climate experienced by men. One argument "suggests that if affirmative action for women is applied in the admission process to $\mathrm{PhD}$ programs and/or at the hiring stage, but not at the tenure stage, then this factor might help explain why fewer women pass the tenure hurdle" (Ginther and Kahn 2004, 212). If white men resent what they perceive as special benefits given to women and minorities in the hiring process, a backlash may occur when these colleagues are called on to vote in tenure decisions.

Additional research is needed on several questions raised by this report. If gender or race does factor into the promotion process, then development programs are still needed to overcome barriers to career advancement within the political science profession. We conclude with our two most perplexing questions: Why are women less likely than men to be associate as compared
11. Actually, it is immobility (staying in the same position for several years) that has been linked to promotion (Farber 1977, 203; Ginther and Hayes 2003, 50).

12. Using 2004 figures, $53 \%$ of female faculty and $47 \%$ of male faculty are single (without dependent children), $59 \%$ of female faculty and $41 \%$ of male faculty are single with dependent children, $41 \%$ of female faculty and $59 \%$ of male faculty are married without dependent children, and $37 \%$ of female faculty and $64 \%$ of male faculty are married with dependent children. Source: US Department of Education, National Center for Education Statistics, 2004 National Study of Postsecondary Faculty (NSOPF:04).

13. Results for the same analyses reported herein for all respondents (including those not in a tenure track position) are available from the authors.

14. Two percent were instructors, lecturers, postdocs or fellows; and we lack information on rank for $6.7 \%$ of respondents. The full professor group includes a few emeriti professors.

15. Our measure of total productivity simply adds the number of publications in each category (e.g., books, articles, chapters). Books are not weighted more heavily than articles.

16. For a similar use of logistic regression models for the study of faculty promotion, see Fang et al. (2000), Ward (2001), and Perna (2001 and 2005).

\section{Why are women less likely than men to be associate as compared to assistant professors? Why is it that the number of publications for women appears to have no effect on their likelihood of being an associate professor over an assistant professor?}

to assistant professors? Why is it that the number of publications for women appears to have no effect on their likelihood of being an associate professor over an assistant professor? Future research will seek answers to these important questions.

\section{ACKNOWLEDGMENT}

The survey on which the analyses reported herein are based was funded by the American Political Science Association. We are indebted to APSA executive director Michael Brintnall for his support, to APSA director of member services and development Sean Twombly for his assistance, and to APSA director of institutional programs Jennifer Segal Diascro for her comments. An earlier version of this paper was presented at the American Political Science Association Annual Meeting, Seattle, September 2011.

\section{NOTES}

1. Different disciplines have distinct normative and procedural practices in the promotion and tenure process (Braxton and Hargens 1996) and the average time to promotion varies by discipline (Ornstein et al. 2007, 9).

2. Table 214, National Center for Education Statistics (http://nces.ed.gov/ programs/digest/d10/tables/dt10_214.asp?referrer=report)

3. Table 256.

4. Table 235 (http://nces.ed.gov/programs/digest/d10/tables/ dt10_235.asp?referrer $=$ report).

5. Table 256.

6. Table 286 (http://nces.ed.gov/programs/digest/d10/tables/dt10_286.asp).

7. See http://www.nsf.gov/statistics/srvydoctorates/. Among US citizens and permanent citizens, $26 \%$ of political science doctorate recipients were of a non-white race or ethnicity (http://www.nsf.gov/statistics/nsf11306/appendix/ excel/tab22.xls).

8. Based on the Survey of Doctorate Recipients (SDR), "in 2001, political science had a lower percentage female who are tenured ( 23 percent) than social science disciplines excluding political science ( 29 percent) and sociology and anthropology (35 percent)" (Ginther 2004, 4).

9. See U.S. Doctorates in the 20 th Century.

10. Note that these studies generally include controls for productivity, demographics, and employer characteristics.
17. The odds-ratio represents the change in the odds of holding the higher rank relative to the lower rank associated with a one-unit change in a particular independent variable. An odds-ratio greater than one represents an increase in the likelihood of being at the higher rank, while an odds-ratio less than one represents a decrease in the likelihood.

18. For multiple imputation work, we used Amelia II version 1.5-2 developed by Honaker, King, and Blackwell (2011). We used the stand alone program of AmeliaView in the Windows environment, downloadable from the developers' website at http://gking.harvard.edu/amelia/. We did not impute any missing values in our dependent variable (i.e., academic promotion); we only imputed the set of explanatory variables. Our data set contains several ordinal and nominal variables and the Amelia II allows users to classify those variables as having noncontinuous distributions according to their characteristics. In addition, we took a (natural) logarithm transformation to any heavily skewed variables or variables with outliers to normalize its distribution. Also, if any variable needed to be bounded by realistically possible numbers (e.g., year of getting PhD degree), we assigned bounds (maximum and minimum values) to those variables using their observed summary statistics. Finally, after AmeliaView produced 5 multiply imputed data sets in a STATA format (.dta), we used Clarify (Tomz, Wittenberg, and King 2003) for data analysis to combine the results.

19. The results for the same analysis based on the smaller number of cases (respondents with missing values excluded) are available from the authors.

20. We also fitted the reported models herein using alternative estimation strategies such as ordered logistic regression and multinomial logistic regression (using associate faculty as a reference category), although we eventually chose to report the results from the binary logistic models. These two alternative methods yielded very similar estimation results across different prediction models to the binary logistic models. We chose to adopt the binary over the ordered logistic models because the former model is more suitable for evaluating which specific sets of variables are significant predictors for a different rank-ladder (i.e., assistant to associate vs. associate to full promotion). Also, we prefer the binary model to the multinomial one since we wanted to avoid reporting negative signs in regression outcomes for positive predictors to the promotion equation (associate to full professor) as we use the associate group as a reference category in the multinomial logistic regressions.

21. We could also have controlled for the year at which the doctoral degree was granted (as this more directly accounts for years of experience), but age and year of degree are highly correlated and we have fewer missing responses on the age variable.

22. Our ranking of $\mathrm{PhD}$ programs has five categories: graduates of one of the top 25 departments (Tier I), compared with graduates from one of the departments ranked in the top 26-50 (Tier II), compared with Tier III, Tier IV, and unranked departments using the Schmidt and Chingos ranking (2007).

23. We asked respondents to report their typical teaching load each year (during the past five years). We include in the analysis the number of undergraduate courses only, as graduate courses are only taught by those in PhD or MA granting departments. 
24. Bivariately, more resources are correlated with being an associate rather than an assistant professor (table $1 \mathrm{~A})$.

25. Looking at bivariate relationships (see table $1 \mathrm{~A}$ ), associates compared to assistants have reviewed more books and have served on more editorial boards. These factors do not emerge as significant in Model $2 \mathrm{C}$ in part because they are correlated with current department rank and with total productivity.

26. Bivariately, the ranking of one's graduate program does affect promotion from associate to full-professor rank (table $1 \mathrm{~A}$ ).

27. Bivariately, being at the full-professor rank is more likely in $\mathrm{PhD}$ programs (for women only). We note that current department rank and $\mathrm{PhD}$ program are highly correlated.

28. Bivariately, reviewing more books (for men and women) and more articles (for women only) are also associated with being a full professor (table 1A).

29. Bivariately, having more children is related to higher rank (assistant compared with associate) for both men and women. With the control for age, however, this factor is not significant. Among women only, associate professors are more likely than assistant professor to be married or partnered.

30. Bivariately, the amount of resources is higher for associate than assistant professors, and among women, assistant professors are more likely than associate professors to be employed in a $\mathrm{PhD}$-granting department.

31. When the professional variables are added (models ${ }_{4} \mathrm{C}$ and ${ }_{4} \mathrm{D}$ ), the coefficient for chairing committees is no longer significant for women, although it remains significant for men. Thus, there is a gender difference in the relationship between chairing committees and rank.

32. Ginther and Hayes (1999; 2003) similarly found significantly different estimates when their models were estimated separately for men and women.

33. Bivariately, the frequency of reviewing books is different for both men and women when associate professors are compared with assistant professors. We remind the reader that these are highly correlated with total publications.

34. When female associate professors are compared with female assistant professors bivariately, associates do have significantly more publications than assistants.

35. The total number of publications is not statistically significant at any level in the females-only model that accounts for their rank promotion from assistan to associate professor; while the publications variable is consistently a strong and significant predictor of academic rank across the other estimation models. Some might question whether this nonsignificance of the publication record variable in model ${ }_{4} \mathrm{D}$ is an artifact of a relatively small number of observations created by splitting the sample, but, in fact, the same variable is statistically significant (at $p<0.1$ ) in the other split model (female faculty promotion from associate to full), although the former sample (assistant to associate, 264) has more cases than the latter (associate to full, 228).

36. Bivariately for women, reviewing articles and serving on editorial boards are also more frequent among full professors as compared with associate professors. Bivariately, female full professors are also more likely than female associate professors to be employed in a PhD-granting department and also more likely to be employed in a higher ranked department. Female full professors teach fewer classes than female associate professors. Female full professors are also less likely to be married than female associate professors. Bivariately, for males, full professors are less likely than associate professors to specialize in IR. Also among males only, coming from a more highly ranked $\mathrm{PhD}$ program is bivariately related to being a full professor.

37. This "similarity" could include similarity in the type of research conducted. Earlier in their careers, women may be exploring somewhat different research questions; those who are tenured may have been socialized into a maleoriented research paradigm, or have already selected into this prior to tenure.

38. The exception is among men only, being married increases the odds of being a full professor compared to an associate professor.

\section{REFERENCES}

Acker, S., and C. Armenti. 2004. "Sleepless in Academe." Gender and Education 16 (1): 3-24.

Allen, M., and T. Castleman. 2001. "Fighting the Pipeline Fallacy." In Gender and the Restructured University: Changing Management and Culture in Higher Education, ed. A. Brooks \& A. Mackinnon, 151-65. Buckingham, England: The Society for Research into Higher Education and Open University Press.

Becker, G. S. 1985. "Human Capital, Effort, and the Sexual Division of Labor" Journal of Labor Economics 3: $\mathrm{S}_{33}-\mathrm{S}_{5} 8$.

Becker, G. S. 1993. Human Capital. Chicago: University of Chicago Press.

Bird, Sharon R., and Laura A. Rhoton. 2011. "Women Professionals' Gender Strategies.” In Handbook of Gender, Work and Organization, ed. E. L. Jeans, D. Knights, \& P.Y. Martin, 245-62. United Kingdom: John Wiley.

Bonilla-Silva, E. 1997. "Rethinking Racism: Toward a Structural Interpretation." American Sociological Review 62: 465-80.
Braxton, John M., and Lowell L. Hargens. 1996. "Variation among Academic Disciplines: Analytical Frameworks and Research.” In Higher Education: Handbook of Theory and Research, ed. John. C. Smart, Volume XI, 1-46.

Cole, J. R. 1979. Fair Science: Women in the Scientific Community. New York: Free Press.

Cotter, D.A., J. M. Hermsen, S. Ovadia, and R. Vanneman. 2001. "The Glass Ceiling Effect." Social Forces 8o (2): 655-81.

Dey, E. L. 1994. "Dimensions of Faculty Stress: A Recent Survey." Review of Higher Education 17: 305-22.

DiTomaso, Nancy, Corinne Post, D. Randall Smith, George F. Farris, and Rene Cordero. 2007. "Effects of Structural Position on Allocation and Evaluation Decisions for Scientists and Engineers in Industrial R\&D." Administrative Science Quarterly 52 (2): 175-207.

Doering, Richard. 1972. "Publish or Perish: Book Productivity and Academic Rank at Twenty-Six Elite Universities." The American Sociologist 7 (9): 11-13.

England, P., G. Farkas, B. S. Kilbourne, and T. Dou. 1988. "Explaining Occupational Sex Segregation and Wages: Findings from a Model with Fixed Effects." American Sociological Review 53: 544-58.

Eveline, Joan. 2004. Ivory Basement Leadership: Power and Invisibility in the Changing University. Crawley, WA: University of Western Australia Press.

Fang, D., E. Moy, L. Colburn, and J. Hurley. 200o. "Racial and Ethnic Disparities in Faculty Promotion in Academic Medicine." The Journal of the American Medical Association 284 (9): 1085-92.

Farber, Stephen. 1977. "The Earnings and Promotion of Women Faculty: Comment.” The American Economic Review 67 (2): 199-206.

Feagin, Joe R., and Clairece B. Feagin. 1986. Discrimination American Style: Institutional Racism and Sexism. Malabar, FL: R. E. Krieger.

Ginther, Donna K. 2004. "Gender Differences in Salary and Promotion in Political Science." Paper prepared for presentation at the American Political Science Association Annual Meeting in Chicago.

Ginther, Donna K., and Kathy J. Hayes. 1999. "Gender Differences in Salary and Promotion in the Humanities." The American Economic Review 89 (2): 397-402.

. 2003. Gender Differences in Salary and Promotion for Faculty in the Humanities 1977-95. Journal of Human Resources 38 (1): 34-73.

Ginther, Donna K., and Shulamit Kahn. 2004. "Women in Economics: Moving Up or Falling Off the Academic Career Ladder?" The Journal of Economic Perspectives 18 (3): 193-214.

Heilman, Madeline E. 2001. "Description and Prescription: How Gender Stereotypes Prevent Women's Ascent Up the Organizational Ladder." Journal of Social Issues 57 (4): 657-74.

Hesli, Vicki, and Barbara Burrell. 1995. "Faculty Rank among Political Scientists and Reports on the Academic Environment: The Differential Impact of Gender on Observed Patterns." PS: Political Science and Politics 28 (2): 101-11.

Hesli, Vicki, Evelyn C. Fink, and Diane Duffy. 2003. "The Role of Faculty in Creating Student Experience: Survey Results from the Midwest Region, Part II." PS Political Science and Politics 36 (4): 801-04.

Hesli, Vicki, and Jae Mook Lee. 2011. "Faculty Research Productivity: Why Do Some of Our Colleagues Publish More Than Others?" PS: Political Science and Politics 44 (2): 393-408.

Honaker, J., Gary King, and M. Blackwell. 2011. Amelia II: A Program for Missing Data. http://r.iq.harvard.edu/docs/amelia/amelia.pdf. Accessed on July 18, 2011.

Jackson, Jerlando F. L., and Elizabeth M. O'Callaghan. 2009. “What Do We Know about Glass Ceiling Effects? A Taxonomy and Critical Review to Inform Higher Education Research." Research in Higher Education 50: 460-82.

Jacobs, J. A. 2004. “The Faculty Time Divide.” Sociological Forum 19 (1): 3-27.

Jacobs, J. A., and S.E. Winslow. 2004a. "The Academic Life Course, Time Pressures, and Gender Inequality." Community Work and Family 7 (2): 143-61.

. 2004b. "Overworked Faculty: Job Stresses and Family Demands." Annals: American Academy of Political and Social Science 596: 104-29.

Johnson, G. E., and F. P. Stafford. 1974. "The Earnings and Promotion of Women Faculty." American Economic Review 64 (6): 888-903.

Kahn, Shulamit. 1993. "Gender Differences in Academic Career Paths of Economists." American Economic Review 83 (2): 52-56.

. 1995. "Women in the Economics Profession." Journal of Economic Perspectives 9 (4): 193-205.

Katz, David A. 1973. "Faculty Salaries, Promotions, and Productivity at a Large University." The American Economic Review 63 (3): 469-77.

Krefting, Linda A. 2003. "Intertwined Discourses of Merit and Gender: Evidence from Academic Employment in the USA." Gender, Work \& Organization 10 (2): $260-78$. 
Kulis, S., and D. Sicotte. 2002. "Women Scientists in Academia: Geographically Constrained to Big Cities, College Clusters, or the Coasts?" Research in Higher Education 43 (1): 1-30.

Lee, Sharon M. 2002. "Do Asian American Faculty Face a Glass Ceiling in Higher Education?" American Educational Research Journal 39 (3): 695-724.

Lewis, L.S. 1998. Scaling the Ivory Tower: Merit and Its Limits in Academic Careers, 2nd ed. New Brunswich, NJ: Transaction Publishers.

Lewis, Lionel S. 1967. "Publish or Perish: Some Comments on a Hyperbole." Journal of Higher Education 38 (2): 85-89.

Lin, N. 2001. Social Capital: A Theory of Social Structure and Action. New York: Cambridge University Press.

Long, J. S. 2001. From Scarcity to Visibility: Gender Differences in the Careers of Doctoral Scientists and Engineers. Washington, DC: National Academy Press.

Long, J. Scott, Paul D. Allison, and Robert McGinnis. 1993. "Rank Advancement in Academic Careers: Sex Differences and the Effects of Productivity." American Sociological Review 58: 703-22.

Long, J. S., and M. F. Fox. 1995. "Scientific Careers: Universalism and Particularism." Annual Review of Sociology 21: 45-71.

Mason, M. A., and M. Goulden. 2002. "Do Babies Matter: The Effect of Family Formation on the Lifelong Careers of Academic Men and Women." Academe 88 (6): 21-28.

-2004. "Marriage and Baby Blues: Redefining Gender Equity in the Academy." Annals: American Academy of Political and Social Science 596: 87-103.

McBride Stetson, Dorothy, Diane Wall, Diane Blair, Mary Ellen Guy, Erika Fairchild, David Canon, Cheryl Brown, and Committee on the Status of Women, Southern Political Science Association. 1990. "The Status of Women in PhD Department." PS: Political Science and Politics 23 (1): 82-86.

McDowell, John M., Larry D. Singell, Jr., and Mark Stater. 2006. "Two to Tango: Gender Differences in the Decisions to Publish and CoAuthor." Economic Inquiry 44 (1): 153-168.

McDowell, John M., Larry D. Singell, Jr., and James P. Ziliak. 1999a. "Cracks in the Glass Ceiling: Gender and Promotion in the Economics Profession." American Economic Review 89 (2): 392-96.

- 1999b. "Gender and Promotion in the Economics Profession." Industrial and Labor Relations Review 54 (2): 224-44.

McDowell, John M., and Janet Kiholm Smith. 1992. "The Effect of Gender Sorting on the Propensity to Coauthor." Economic Inquiry 30: 68-82.

Merton, Robert. [1942] 1973. “The Normative Structure of Science.” In The Sociology of Science, 267-78. Chicago: University of Chicago Press.

Milem, J. F., J. Sherlin, and L. Irwin. 2001. "The Importance of Collegial Networks to College and University Faculty." In Working Equal: Academic Couples as Collaborators, ed. E. G. Creamer, 146-66. New York: Routledge Falmer.

Mincer, J., and S. Polachek. 1974. "Family Investments in Human Capital." Journal of Political Economy 82 (2): S76-S108.

Morgan, L. A. 1998. "Glass Ceiling Effect or Cohort Affect? A Longitudinal Study of Gender Earnings Gaps for Engineers, 1982-1989." American Sociological Review 63 (4): 479-93

Morrison, Emory, Elizabeth Rudd, and Maresi Nerad. 2011. "Onto, Up, Off the Academic Faculty Ladder: The Gendered Effects of Family on Career Transitions for a Cohort of Social Science PhDs." The Review of Higher Education 34 (4): 525-53.

National Science Foundation. 2011. "Survey of Earned Doctorates." The National Center for Science and Engineering Statistics (NCSES) (http://www.nsf.gov/ statistics/srvydoctorates/).

National Science Foundation, Division of Science Resources Statistics. 2004. Gen der Differences in the Careers of Academic Scientists and Engineers, NSF 04-323, Project Officer Alan I. Rapoport. Arlington, VA: National Science Foundation.

O'Leary, V. E., and J. M. Mitchell. 1990. "Women Connecting with Women: Networks and Mentors." In Storming the Tower: Women in the Academic World, ed. S. Lie and V. E. O'Leary. London: Kogan Page.

Ornstein, Michael, Penni Stewart, and Janice Drakich. 2007. "Promotion at Canadian Universities: The Intersection of Gender, Discipline, and Institution." Canadian Journal of Higher Education 37 (3): 1-25.

Over, Ray. 1993. "Correlates of Career Advancement in Australian Universities." Higher Education 26: 313-29.
Perna, Laura W. 2001. "Sex and Race Differences in Faculty Tenure and Promotion." Research in Higher Education 42 (5): 541-67.

- 2005. "Sex Differences in Faculty Tenure and Promotion: The Contribution of Family Ties." Research in Higher Education 46 (3): 277-307.

Reskin, B. F. 2003. "Including Mechanisms in Our Models of Ascriptive Inequality." American Sociological Review 68: 1-21.

Roos, Patricia A., and Mary L. Gatta. 2009. "Gender (In) equity in the Academy: Subtle Mechanisms and the Production of Inequality." Research in Social Stratification and Mobility 27 (3): 77-200.

Rosenfeld, R. A., and J. A. Jones. 1987. "Patterns and Effects of Geographic Mobility for Academic Women and Men." Journal of Higher Education 58: 493-515.

Rothgeb, John M., Jr., and Betsy Burger. 2009. "Tenure Standards in Political Science Departments: Results from a Survey of Department Chairs." PS: Political Science \& Politics 42 (3): 513-19.

Rowe, Mary P. 1990. "Barriers to Equality: The Power of Subtle Discrimination to Maintain Unequal Opportunity." Employee Responsibilities and Rights Journal 3 (2): 153-63.

Rudd, E., E. Morrison, R. Sadrozinski, M. Nerad, and J. Cerny. 20o8. "Equality and Illusion: Gender and Tenure in Art History Careers." Journal of Marriage and Family 70: 228-238.

Sax, Linda J., Linda Serra Hagedorn, Marisol Arredondo, and Frank A. Dicrisi III. 2002. "Faculty Research Productivity: Exploring the Role of Gender and Family-Related Factors," Research in Higher Education 43 (4): 423-45.

Schmidt, B. M., and M. M. Chingos. 2007. "Ranking Doctoral Programs by Placement: A New Method." PS: Political Science and Politics 40 (3): 523-29.

Stewart, Penni, Michael Ornstein, and Janice Drakich. 2009. "Gender and Promotion at Canadian Universities." CRS/RCS 46 (1): 59-85.

Tajfel, H., and J. C. Turner. 1986. "The Social Identity Theory of Intergroup Behaviour.” In Psychology of Intergroup Elations, eds. S. Worchel and W. G. Austin, 7-24. Chicago: Nelson-Hall.

Tien, Flora F. 2007. “To What Degree Does the Promotion System Reward Faculty Research Productivity?” British Journal of Sociology of Education 28 (1): 105-123.

Tierney, W. G., and E. M. Bensimon. 1996. Promotion and Tenure: Community and Socialization in Academe. Albany: State University of New York Press.

Tomz, Michael, Jason Wittenberg, and Gary King. 2003. "CLARIFY: Software for Interpreting and Presenting Statistical Results." Journal of Statistical Software 8 (1): 1-19.

Toutkoushian, R. 1999. "The Status of Academic Women in the 1990s. No Longer Outsiders, but Not Yet Equals." Quarterly Review of Economics and Finance 39: 679-98.

Van Assendelft, Laura, Wendy Gunther-Canada, and Julie Dolan. 2001. “The Status of Women in Political Science Departments in the South: Results of the Millennium Survey." PS: Political Science and Politics 34 (2): 333-38.

Ward, K., and L. Wolf-Wendel. 2004. "Academic Motherhood: Managing Complex Roles in Research Universities." The Review of Higher Education 27 (2): 233-57.

Ward, Melanie E. 2001. "Gender and Promotion in the Academic Profession." Scottish Journal of Political Economy 48 (1): 283-302.

Wenneras, C., and A. Wold. 1997. "Nepotism and Sexism in Peer-Review." Nature 387: 341-43.

Wolfinger, N. H., M. A. Mason, and M. Goulden. 2008. "Problems in the Pipeline: Gender, Marriage, and Fertility in the Ivory Tower." Journal of Higher Education $79(4): 389-405$.

Woodring, Paul. 1964. "Must College Teachers Publish or Perish?" Saturday Review 48 (June 20): 45-46.

Yoder, J. D. 1985. “An Academic Woman as Token: A Case Study.” Journal of Social Issues 41: 61-72.

Zuckerman, H. 1987. "The Careers of Men and Women Scientists: A Review of Current Research." In Women: Their Underrepresentation and Career Differentials in Science and Engineering, ed. L. S. Dix. Washington, DC: National Academy of Sciences. 


\section{APPENDIX A: Survey Methodology}

\section{QUESTIONNAIRE DESIGN}

In 2005, the APSA Committee on the Status of Women in the Profession (CSWP) proposed to the president of APSA that the association conduct research associated with the recommendations that emerged from the March 2004 Workshop on Women's Advancement in Political Science organized by Michael Brintnall and Linda Lopez (American Political Science Association), Susan Clarke (University of Colorado, Boulder), and Leonie Huddy (Stony Brook University). After the research proposal was approved, the CSWP used questionnaires that had been used in research published by Hesli and Burrell (1995), Hesli, Fink, and Duffy (2003) and Hesli, DeLaat, Youde, Mendez, and Lee (2006) to develop a new survey instrument. Additional questions were added from questionnaires developed by the National Research Council and the University of Michigan's fall 2001 Survey of Academic Climate and Activities, which was created for an NSF ADVANCE project. The following reports were also used to help generate questions.

Blau, F. 2002. Report of the Committee on the Status of Women in the Economics Profession. American Economic Review 92: 516-20.

Commission on Professionals in Science and Technology (CPST). 2000. Professional Women \& Minorities: A Total Human Resource Data Compendium, 13th edition. Washington, DC: CPST.

Creamer, Elizabeth. 1998. Assessing Faculty Publication Productivity: Issues of Equity. ASHE-ERIC Higher Education Report 26 (2). Washington, DC: The George Washington University.

Fox, Mary Frank. 1995. “Women and Scientific Careers.” In Handbook of Science and Technology Studies, eds. S. Jasanoff, J. Markle, J. Petersen, and T. Pinch, 205-223. Newbury Park, CA: Sage.

Fox, Mary Frank. 1998. "Women in Science and Engineering: Theory, Practice, and Policy in Programs." Signs: Journal of Women in Culture and Society 24 (Autumn): 201-23.

Sarkee, Meredith Reid, and Nancy E. McGlen. 1992. Confronting Barriers: The Status of Women in Political Science. Journal of Women, Politics \& Policy 12 (4): 43-86.

A draft of the questionnaire was circulated to the members of the APSA status committees. The questionnaire was revised and expanded to address the concerns of the members of the status committees. The instrument was pilot tested by distributing it to all political science faculty members at one research university and at one private four-year college. The feedback from the pilot test was used to make further revisions in the questionnaire.

\section{SAMPLE SELECTION}

We used as our target population the names contained within the APSA "faculty" file. We used this file of 11,559 names to create a sample population file of size 5,179 names. The original "faculty" file was stratified by department size. To ensure the adequate representation of faculty members from medium and small size schools we over-sampled from these. Names were selected randomly from the "faculty" file for the "sample" file.

\section{SURVEY PROCEDURE}

Using e-mail addresses, all persons in the sample file were sent a letter of invitation to participate in the study from the executive director and the president of the APSA. Incorrect e-mail addresses (addresses that bounced back) were replaced with random selections from the "faculty" file. These persons were also mailed an invitation letter. The cleaned "survey" file was sent to the Survey Research Center at the Pennsylvania State University (SRC).

Individuals in the sample were sent an e-mail from SRC inviting them to participate in the survey. This invitation included a link to the web-based survey containing a unique identifier for each potential participant. Only one completed survey was allowed for each identifier. The initial invitation was e-mailed to respondents on August 27, 2009. Follow-up reminders were sent to nonresponders on September 10,2009 , September 24, 2009, October 8, 2009, and October 29, 2009. From among the 5,179 original addresses, 1,399 completed the survey (252 invalid addresses, 105 refusals, and 3,423 nonrespondents).

Among the total set of respondents, $68 \%$ are men and $32 \%$ are women. According APSA data, the percent of women in the population from which we drew the sample (all political science faculty members in the United States) was $28 \%$ (in 2009). Table A1 shows the percent of survey respondents at each rank alongside of the percent of faculty members in each rank throughout the United States according to APSA data for 2009. With regard to respondents' gender, among assistant professors, $45 \%$ were women; among associates, $28 \%$ were women; and among full professors, $24 \%$ were women. The corresponding numbers for the population as a whole are in the table A1.

Table $A_{1}$

\section{Survey Respondents and the Population}

\begin{tabular}{l|cc|cc}
\multirow{2}{*}{ RANK } & \multicolumn{2}{|c|}{ PERCENT OF TOTAL } & \multicolumn{2}{c}{ PERCENT WITHIN RANK WHO ARE FEMALE } \\
\cline { 2 - 5 } & $\begin{array}{c}\text { Survey Respondents } \\
\text { (tenure track only) }\end{array}$ & $\begin{array}{c}\text { The Population } \\
\text { (2009 APSA data) }\end{array}$ & $\begin{array}{c}\text { Survey Respondents } \\
\text { (tenure track only) }\end{array}$ & $\begin{array}{c}\text { The Population } \\
\text { (2009 APSA data) }\end{array}$ \\
\hline Assistant & 28 & 28 & 45 & 39 \\
\hline Associate & 26 & 26 & 28 & 30 \\
\hline Full & 37 & 35 & 24 & 19 \\
\hline
\end{tabular}




\section{APPENDIX B: Variables Included}

Dependent Variable: Faculty Rank: "Title of your primary current appointment"

We created an ordinal variable using the following coding: 1 (instructors, lecturers, postdocs, and fellows), 2 (assistant professors), 3 (associate professors) and 4 (full professors, emeritus, and administrative positions).

Independent Variables:

Female: "What is your gender? a. Male, b. Female, c. Transgender" The dummy variable equals 1 if the response is b.

Minority: "Do you identify yourself as a member of an ethnic and racial minority group? a. Yes, b. No, c. Don't know" The dummy variable equals 1 if the response is a.

Married: "What is your personal status? a. Never married, b. Married (first time), c. Married (second or third time), d. Member of an unmarried opposite or same-sex partnership, e. Separated/divorced, f. Widowed" The dummy variable equals 1 if the response is b, c, or $d$.

Number of Children: "Do you or a spouse/partner of yours have any children? a. Yes (If yes, how many?), b. No" An interaction variable between a dummy for having children (response a.) and the number of children specified.

Number of years to complete PhD: Two questions: “In what year did you begin work on your PhD?' and 'In what year did you obtain your degree?" The reported variable is the year of getting $\mathrm{PhD}$ degree minus the year of beginning the degree program.

PhD Program Rank: Question: “From which university did you obtain your degree?" The program is ranked based on Schmidt and Chingos (2007); Top 25 (1), Top 26-50 (2), Top 51-75 (3), Top 76-86 (4), and Unranked (5). Foreign degrees and degrees from majors other than political science were set as missing. Then the score is reversed so that higher numbers represent higher ranked programs.

Teaching Load: "During the past five years, what is your typical teaching load each year? (If in your current position for less than five years, base this on the period since your appointment.)

Number of undergraduate courses"

Number of Committees Chaired: "In a typical year during the past five years, how many committees do you chair?"

Amount of Student Advising: "For how many of each of the following types of individuals do you currently serve as official advisor? __ Undergraduates, __MA students, __PhD students, __ postdocs"

The variable was generated by following steps. First, dummy variables were created to represent higher than average advising for each student group. For example, the respondent would receive a "1" on undergraduate advising if their reported number of undergraduate students advised was higher than the overall mean for that question. The same coding rule was applied to other student groups such as MA students, doctoral students and postdocs. Next we counted the overall number of 1's from those four dummies.

Count of Overall Resources: "Have you received any of the following resources as a result of your own negotiations, the terms of an award, or as part of an offer by the university, since your initial contract at your current position? If so, please check all that apply."

\begin{tabular}{|l|l|l|} 
ASKED/BARGAINED FOR BY ME & PART OF AN EXTERNAL AWARD & OFFERED BY UNIVERSITY
\end{tabular}

\begin{tabular}{l|l|l|l}
\hline Course release time & & & \\
\hline Research assistant & & & \\
\hline Discretionary funds & & & \\
\hline Travel funds & & & \\
\hline Summer salary & & &
\end{tabular}

Using the count command, we added up the total number of checks for all rows and all columns.

PhD. Program: “Type of department where you are employed: a. PhD granting program, b. MA granting program, c. Department within a 4-year college, d. Department within a 2-year college, e. Other academic unit (specify)" The dummy variable equals 1 if the response is a.

MA Program: Same question as above, with the dummy variable equals to 1 if the response is $b$.

Private Institution: "Is this a public or a private institution? a. Public, b. Private" The dummy variable equals to 1 if the response is b.

Subfield Dummies: "Which of the following best describes your current primary field of teaching and research? a. American, b. Comparative, c. International Relations, d. Theory, e. Methods, f. Other ( please specify)"

American subfield equals 1 if the response is a.

Comparative Subfield equals 1 if the response is $b$.

IR Subfield equals 1 if the response is $\mathrm{c}$.

Theory Subfield equals 1 if the response is $d$.

More than 7 years in current position: “Have you been in your current position more than 7 years?"

(continued) 


\section{APPENDIX B: (Continued)}

Current Program Ranking: A ranking of the department where the respondent is currently working. The program is ranked based on Schmidt and Chingos (2007); Top 25 (1), Top 26-50 (2), Top 51-75 (3), Top 76-86 (4), and Unranked (5). Then the score is reversed so that higher numbers represent higher ranked department.

Total Productivity: Question: "For your entire career, please give your best estimate of the number you have produced or have been awarded for each of the following.

number of articles published in referred academic or professional journals

number of monographs (books) published

number of books edited

number of book chapters published"

All missing values of articles, monographs, edited books, and book chapters are set to zero, then we took a logarithmic transformation of the sum of these items plus one.

Departmental Influence: A count of responses $b$ and $c$ for the following questions:

"For each item, please check the box that best corresponds to how much influence you feel you have over the following matters in your department(s). (a. Less influence than I would like, b. About the right amount of influence, c. More influence than may be appropriate)

46. Department curriculum decisions

47. Size of salary increases I receive

48. Selecting new students (graduate or undergraduate)

49. Selecting new faculty members to be hired

50. Determining who gets tenure

51. Selecting the next unit head" 